\title{
LABOUR AND THE WORLD TRADE ORGANIZATION: TOWARDS A RECONSTRUCTION OF THE LINKAGE DisCOURSE
}

\author{
LUKE L ARNOLD*
}

[As the World Trade Organization approaches its ten-year anniversary, the long-discussed issue of linking the right to trade with the enforcement of certain labour standards continues to persist. However, the discourse on the issue has hit a stalemate of late. In the hope of overcoming the stalemate and moving toward effective solutions on the issue, this paper explains and examines four types of "conceptual differentiations" that currently underpin a significant portion of the labour linkage discourse. The "conceptual differentiations" examined are trade/non-trade; north/south; liberalisation/protectionism; economic development/poverty; consumption/ production; universalist/relativist; WTO/ILO; and sanctions/welfare. A policy proposal for further discussion on the issue is then presented, based on a re-conceptualisation of the "conceptual differentiations" discussed.]

\footnotetext{
* BA (Indonesian Studies), LLB (Hons 1) (Melb). The author would like to thank his colleagues at both the Asian Law Centre at the University of Melbourne and the International Labour Organization's Jakarta Office. Needless to say, the usual caveat applies with regard to all personal views expressed.
} 


\section{INTRODUCTION}

From tabloid stories to academic debate, the current unprecedented volume of international trade is increasingly being spoken of within the same stories as working conditions and labour markets. Within this discourse, the labour-related ramifications of increased international trade are used to both support and criticise the institutions that regulate it. In particular, the World Trade Organization (WTO) is hailed at one end of the spectrum as a framework through which more and better jobs are being created, yet at the other is protested against as a driving force behind the exploitation of workers. The WTO itself, however, has been largely silent on labour-related issues. The fact that this silence is accompanied by a growth in the WTO's overall scope and reach into both international and domestic economic life has therefore served to intensify the discourse on the "link" between labour and trade. ${ }^{1}$ Within this discourse, some actors are in favour of the WTO playing a direct role in enforcing certain practices with regard to the treatment of workers. This "pro-linkage" argument is not new; the Charter of the International Trade Organization, the original institution designed nearly sixty years ago to regulate international trade, contained a "social clause" that would have required its members to prevent "unfair labour conditions". ${ }^{2}$ What is new, however, is the context within which the labour linkage discourse is taking place and the different types of pro- and antilinkage arguments this has produced.

One current feature that particularly stands out in the labour linkage discourse is that pro- and anti-linkage proponents are talking past one another. ${ }^{3}$ Somewhat of a stalemate has come about, in that the types of arguments appearing in the discourse rarely engage with each other. Part of the problem is that much of the discourse is based on a set of "conceptual differentiations", which in turn are based on largely unquestioned assumptions. ${ }^{4}$ This has resulted in the discourse leaving a large range of policy options unexplored. This author therefore believes the labour linkage discourse should continue, not as an end in itself but as a way of threshing out all possibilities before the concept of linkage is abandoned in favour of the status quo or a complete overhaul of the system. As such, this paper aims to stimulate the labour linkage discourse into exploring new ground. Part II provides a brief overview of the background behind the current stalemate. Part III explains and examines four types of "conceptual differentiations" that currently underpin a significant portion of the labour linkage discourse. These relate to the concept of linkage; the actors within the labour linkage discourse; the theologies sustaining the anti-linkage

\footnotetext{
${ }^{1}$ Frank J. Garcia, Trade and Justice: Linking the Trade Linkage Debates, 19 U. PA. J. INT'L ECON. L. 391, 393 (1998).

${ }^{2}$ Havana Charter for an International Trade Organization, art 7, U.N. Doc E/CONF.2178 (1948). Due to several factors, in particular the fact that the Charter was never ratified by the United States, the International Trade Organization was never established.

${ }^{3}$ Raj Bhala, Clarifying the Trade-Labor Link, 37 COLUM. J. TRANSNAT'L L.11, 55 (1998).

${ }^{4}$ See below Part III.
} 
argument; and regime-related linkage issues. For the purposes of getting the ball rolling on the reinvigoration of the labour linkage discourse, Part IV then puts forward a model of linkage that touches on some of the possibilities opened up by an examination of the "conceptual differentiations" addressed in Part III.

\section{The Stalemate in the Labour Linkage Discourse}

For the past 25 years, various governments of the United States, Canada, and the European Union, along with a broad range of civil society organisations throughout the world, have argued that international trade law should in some way be linked to labour standards. ${ }^{5}$ At the 1994 Marrakesh Ministerial Conference which brought the WTO into being, almost every delegation brought up the issue. Polarised views on it, however, prevented an agreement being reached. ${ }^{6}$ In particular, several large less economically developed countries (LEDCs), including India, China and Brazil, expressed a keen desire to see the issue dropped from the WTO agenda entirely. ${ }^{7}$ The extent of this disagreement with the pro-linkage position resulted in the cancellation of a planned address by the Director-General of the International Labour Organization (ILO) to the 1996 Singapore Ministerial Conference. In the Declaration that resulted from this Conference, the ministers stated that the ILO, as opposed to the WTO, "is the competent body to set and deal with [labour] standards". The ministers also declared that they "reject the use of labour standards for protectionist purposes, and agree that the comparative advantage of countries, particularly low-wage developing countries, must in no way be put into question." At the Seattle Ministerial in 1999, a Clinton Administration proposal that a Working Group be established within the WTO to examine the linkage issue in greater detail was rejected. ${ }^{10}$ Support for the Singapore Ministerial Declaration was later reiterated at the Doha Ministerial in 2001. ${ }^{11}$

\footnotetext{
${ }^{5}$ See, eg, Daniel A. Zaheer, Breaking the Deadlock: Why and How Developing Countries Should Accept Labor Standards in the WTO, 9 STAN. J. L. BuS. \& FIN. 69, 71 (2003).

${ }^{6}$ World Trade Organization, Briefing Note: Trade and Labour Standards

<http://www.wto.org/english/thewto_e/minist_e/min99_e/english/about_e/18lab_e.htm> (last visited Aug. 17, 2004).

${ }^{7}$ See, eg, Gary S. Fields, International Labor Standards and Decent Work: Perspectives from the Developing World in InTERnational Labor STANDARDS: Globalisation, TRADE, and PubliC POLICY, 70 (Robert J. Flanagan \& William B. Gould IV eds., 2003).

${ }^{8}$ Singapore Ministerial Declaration, WTO Doc WT/MIN(96)/DEC (1996) [4] (Declaration adopted at the Singapore Ministerial Conference on 13 December 1996). (Emphasis added.) The Declaration did go on to reaffirm WTO support for the very limited "existing collaboration" between the WTO and the ILO Secretariats.

${ }^{9}$ Ibid.

${ }^{10}$ Sarah H. Cleveland, Why International Labor Standards? in INTERNATIONAL LABOR STANDARDS: Globalization, Trade and Public Policy, 149 (Robert J. Flanagan \& William B. Gould IV eds., 2003).

${ }^{11}$ Doha Ministerial Declaration, WTO Doc WT/MIN(01)/DEC/1 (2001) [8] (Declaration adopted at the Doha Ministerial Conference on 14 November 2001).
} 
The pro-linkage argument is essentially two-pronged: first, pro-linkage proponents argue that an absence of linkage is harmful to workers in LEDCs; second, the absence of linkage is said to also be harmful to workers in economically developed countries (EDCs). The argument that an absence of linkage is harmful to workers in LEDCs is based on the notion that, in many of these countries, the market failures which produce poor labour conditions are often not corrected by national policies. ${ }^{12}$ As such, linkage is argued as necessary to provide a financial disincentive for countries to export products that are produced under what are deemed unacceptable working conditions. Given the financial rewards available from being able to export, these disincentives will in turn supposedly motivate employers, governments and unions into exerting their best efforts to prevent harmful treatment towards workers. The argument that linkage is required for the sake of workers in EDCs is sometimes put in openly protectionist terms, as in one United States union's claim that linkage is required in order to "protect good union jobs in this country". 13 Others couch the argument in terms of EDC workers being exposed to an unfair race to the bottom, ${ }^{14}$ or that countries which undermine hard-won labour standards in EDCs are engaging in a kind of "social dumping". ${ }^{15}$ Linkage is therefore seen as necessary to prevent a "beggar thy neighbour" scenario, whereby countries are forced to undermine each other's labour standards in order to remain economically competitive. $^{16}$

Anti-linkage proponents often respond to the call for linkage by claiming that those behind the call are simply acting in their own self-interest. Former Malaysian Prime Minister Mahathir, for example, has stated that "sanctimonious pronouncements", such as those made by North Americans about the welfare of Malaysian workers, "are likely to be motivated by a... selfish desire to put as many obstacles as possible in the way of anyone attempting to catch up and compete with the West." LEDCs opposed to labour linkage claim that their future development relies on maintaining a competitive advantage by keeping wages sufficiently lower than in EDCs. These LEDCs also claim that it is hypocritical of EDCs to seek to impose labour standards on LEDCs, given that EDCs had scant regard for labour standards during the early stages of their own economic growth. ${ }^{18}$ The fact that labour linkage

\footnotetext{
${ }^{12}$ Robert J. Flanagan, Labor Standards and International Competitive Advantage in INTERNATIONAL Labor Standards: Globalisation, Trade, And Public Policy, 15 (Robert J. Flanagan \& William B. Gould IV eds., 2003).

${ }^{13}$ Bruce Raynor, President of the United States Union of Needle-Trades, Industrial and Textile Employees, cited in Fields, supra note 7, at 68.

${ }^{14}$ See, $e g$, Michael J. Trebilcock \& Robert Howse, The Regulation of International Trade 454 (2d ed. 1999).

${ }^{15}$ See, eg, Elissa Alben, GATT and the Fair Wage: a Historical Perspective on the Labor-Trade Link, 101 COLUM. L. REV. 1410, 1415 (2001). The related notion of regulatory subsidies is discussed below in Part III(C)(1).

${ }^{16}$ TREBILCOCK \& HowSE, supra note 14, at 12.

${ }^{17}$ Mahathir Mohamad, East Asia Will Find Its Own Roads to Democracy, Int'l Herald Trib., May 17, 1994 at 6.

${ }^{18}$ On this point, Kennedy draws an analogy between labour rights in international trade and international humanitarian law, in that both involve those with rulership seeking to prohibit the practices and/or weapons which they no longer require: David Kennedy, Reassessing International Humanitarianism,
} 
proponents are usually not arguing for the right of workers in LEDCs to simply migrate to EDCs in order to enjoy EDCs' higher working standards is also cited as an example of the hypocrisy and protectionist motives behind many linkage arguments. ${ }^{19}$

Some anti-linkage commentators do recognise that there is an "altruistic" set of prolinkage arguments, but claim that that these arguments are misguided and have been strategically appropriated by "egotistical" desires. ${ }^{20}$ They argue that the altruistic desire to see an end to poverty in the global South ${ }^{21}$ would be best served by economic development rather than labour linkage. ${ }^{22}$ Any sanctions that result from linkage would, it is argued, destroy jobs and therefore harm those whom they are intended to be protecting. ${ }^{23}$ In addition, anti-linkage proponents argue that linkage is an invasion of sovereignty, in that it takes away the nation-state's autonomy over the production processes within its jurisdiction, ${ }^{24}$ and imposes universal standards without regard for local circumstances or preferences. ${ }^{25}$ Labour linkage is portrayed as a concept inimical to the WTO's goal of ending protectionism, ${ }^{26}$ so it is deemed necessary to institutionally cordon off trade from labour by promoting the rigid separation of responsibilities between the WTO and ILO as articulated in the Singapore Ministerial Declaration. ${ }^{27}$ Underlying many of these arguments is a belief that trade is in fact an entirely distinct concept from labour and that attempts to link them are therefore conceptually unsound. ${ }^{28}$

In response to some of the anti-linkage arguments, many pro-linkage advocates have begun to focus on arguing for linkage of a specified set of "core labour rights". 9 This paradigm shift represents what could be termed a deontological approach to labour standards, in which the aim is not to harmonise worldwide labour standards or make an impact upon labour standards across different strata of workplaces (through, for example, the establishment of wage-setting frameworks ${ }^{30}$ ), but to provide a safety net involving the elimination of working conditions "so odious or harmful that it would be better for [the workers exposed to them] not to work at all". ${ }^{31}$ Somewhat of a consensus is forming among pro-linkage advocates that the best way to determine such conditions is by reference to the ILO Declara-

speech delivered at the Allen Hope Southey Memorial Lecture, University of Melbourne, (8 June 2004). See also Bhala, supra note 3, at 27.

${ }^{19}$ JAGDiSH BHAGWATI, IN DEFENSE OF GLOBALIZATION 244 (2004).

${ }^{20}$ See generally Jagdish Bhagwati, The Question of Linkage, 96 AM. J. INT'L L. 126 (2002).

${ }^{21}$ The problems associated with references to the global North and South are discussed below in Part III(B).

${ }^{22}$ See below Part III(C)(2).

${ }^{23}$ See below Part III(D)(3).

${ }^{24}$ See below Part III(C)(3).

${ }^{25}$ See below Part III(D)(1).

${ }^{26}$ See below Part III(C)(1).

${ }^{27}$ See below Part III(D)(2).

${ }^{28}$ See below Part III(A).

${ }^{29}$ See, eg, TREBILCOCK \& HOWSE, supra note 14, at 441-62; Fields, supra note 7, at 64-74; Cleveland, supra note 10, at 137-59; and Zaheer, supra note 5. Contra Alben, supra note 15.

${ }^{30}$ See, eg, Alben, supra note 15 , at 1415.

${ }^{31}$ Fields, supra note 7, at 67. 
tion. ${ }^{32}$ Rather than coming up with a "laundry list" of workplace rights and principles as appears in the European Social Charter, ${ }^{33}$ the ILO Declaration includes just four fundamental rights at work, which all ILO members ${ }^{34}$ are required to uphold (regardless of whether they have ratified the relevant conventions): freedom of association, freedom from forced labour, freedom from child labour and freedom from discrimination. ${ }^{35}$ A broad-based ILO-sponsored commission on globalisation recently found that through "international consensus", it has been established that "this particular set of core labour standards with universal reach constitutes the minimum rules for labour in the global economy." ${ }^{36}$ It is possible to find all the rights contained in the ILO Declaration within the Universal Declaration of Human Rights ${ }^{37}$ an intersection that is reminiscent of the common genesis of international labour law and international human rights law - the abolition of slavery. ${ }^{38} \mathrm{Al}-$ though some supporters of labour linkage identify groups of core rights that include more rights than those identified in the ILO Declaration, ${ }^{39}$ and others would take away some, ${ }^{40}$ there is a growing consensus that the core rights approach to labour linkage is to be preferred over approaches that may directly disturb the ability of countries to build competitive advantages, to some extent, on low-wages. ${ }^{41}$ In spite of such a move, which seems intent to demonstrate that the "trade and labour rights link is not some fanatical or protectionist adventure to attempt harmonisation of conditions across the world", 42 there has not been any significantly fresh debate with anti-linkage proponents; both sides continue to exist as "two solitudes". 43 Part of the reason for this may be underlying, unexamined "conceptual differentiations", to which this paper now turns.

\footnotetext{
${ }^{32}$ ILO Declaration on Fundamental Principles and Rights at Work, adopted at the $86^{\text {th }}$ Session of the International Labour Conference, 18 June 1998.

${ }_{33}^{33}$ Bhala, supra note 3, at 30.

${ }^{34}$ With 177 member states, the ILO has the largest international membership of all the UN-affiliated bodies. (The WTO has 148 member states.)

${ }^{35}$ ILO Declaration art 2.

${ }^{36}$ ILO World Commission on the Social Dimension of Globalization, A Fair Globalization: Creating Opportunities for All (2004) 92.

${ }^{37}$ Universal Declaration of Human Rights, U.N. GAOR, G.A. Res. 217A, $3^{\text {rd }}$ Sess., $183^{\text {rd }}$ plen mtg, U.N. Doc A/810 (1948). Freedom of association is protected under arts 20(1) and 23(4), freedom from being forced to work is protected under arts 4 and 23(1), and discrimination is prohibited under arts 7 and 23(2). Art 5, prohibiting "cruel, inhuman or degrading treatment", can be read as a prohibition on child labour.

${ }^{38}$ Cleveland, supra note 10 , at 137.

${ }^{39}$ Cleveland, for example, would add freedom from employment in ultra-hazardous conditions, a right to subsistence wages and a right to equal protection for migrant workers: Ibid.

${ }^{40}$ The OECD would only prohibit exploitative forms of child labour rather than all forms of child labour: Organisation for Economic Co-operation and Development, Trade, Employment and Labour Standards: A Study of Core Workers' Rights and International Trade (1996). Zaheer would take away antidiscrimination and adopt a phased introduction to the prohibition on child labour: Zaheer, supra note 5, at $98-9$.

${ }^{41}$ Cleveland, supra note 10, at 154 . See also TREBILCOCK \& HOwSE, supra note 14, at 462.

${ }^{42}$ TREBILCOCK \& HOWSE, supra note 14, at 462.

${ }^{43}$ Brian Langille, Labor Standards in the Globalized Economy, in INTERNATIONAL LABOUR STANDARDS AND ECONOMIC INTERDEPENDENCE 330 (Werner Segenberger \& Duncan Campbell eds.,1994), cited in Sundhya Pahuja, Trading Spaces: Locating Sites for Challenge Within International Trade Law, 14 AUST. FEM. L. J. 38, 40 (2000).
} 


\section{III “CONCEPTUAL DifFERENTIATIONS” IN THE LABOUR LINKAGE DISCOURSE}

According to Koskenniemi, legal argument always proceeds by establishing a "system of conceptual differentiations" through which doctrines, positions or rules in support of a particular argument are justified. ${ }^{44}$ This is done by establishing Opposites against which the components of the argument can define themselves and in relation to which position themselves as superior. While dialectic reasoning may be an inevitable aspect of legal argument, ${ }^{45}$ a dynamic discourse requires that the conceptual differentiations upon which its arguments are founded to be constantly exposed to an analysis that reveals their "deep-structure". ${ }^{46}$ What this is often likely to show is that the conceptual differentiations relied upon are not mutually exclusive and are in fact largely mutually dependent. ${ }^{47}$ Such revelations therefore have the potential to pave the way for established conceptual differentiations to be reconstructed and for the discourse to continue in a reinvigorated form.

Although labour linkage discourse is by no means new, ${ }^{48}$ the conceptual differentiations that form the discourse as a whole are yet to undergo a thorough analysis. This may partly explain the stalemate at which the debate currently finds itself. This Part therefore seeks to identify the key conceptual differentiations underpinning the labour linkage discourse, and to question the assumptions upon which they rest. These conceptual differentiations can be understood as falling into four broad and interrelated types of dichotomies: the conceptual dichotomy, the actors dichotomy, theological dichotomies, and regime dichotomies. These four categories will be addressed in turn.

\section{A The Conceptual Dichotomy}

The most central conceptual differentiation in the linkage discourse relates to the concept of linkage itself. This argument proceeds by establishing a dichotomy between "trade" and "non-trade" issues, and assigning labour to the latter. After classifying labour as a non-trade issue, the anti-linkage discourse then describes labour in the context of linkage as "contamination" 49 or as one of many "insects on a warm night", attracted to the bright light of the WTO. ${ }^{50}$ Three former

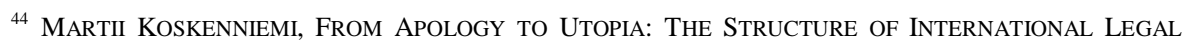
ARGUMENT xxi (1989).

${ }^{45}$ Or, in fact, any natural process: See generally Friedrich Engels, Dialectics of Nature (Clemens Dutt trans, first published 1882, 1940 ed) [trans of: Dialektik der Natur].

${ }^{46}$ KOSKENNIEMI, supra note 44 , at $\mathrm{x}$ vii.

${ }^{47}$ Ibid xxi.

${ }^{48}$ See above Parts I and II.

${ }^{49}$ See, eg, CUTS Centre for International Trade, Economics and Environment, Enough Is Enough: Third World Intellectuals and NGOs' Statement Against Linkages, Consumer Unity and Trust Society (India), 15 November 1999 <http://cuts-international.org/linkages-twinsal.htm> (last visited Sep. 10, 2004).

${ }^{50}$ Steve Charnovitz, Rethinking WTO Trade Sanctions, 95 AM. J. INT’L L. 792, 832 (2001).
} 
GATT $^{51}$ /WTO Directors-General have also warned that "the WTO cannot be used as a Christmas tree on which to hang any and every good cause". 52 Trade is thus conceived as pure, enlightening and value-free, while labour linkage is impure, annoying and decadent.

What this binary logic overlooks, however, is the simple economic fact that traded goods or services will inevitably involve input in the form of human labour. ${ }^{53}$ While Smith and Marx may not have agreed on who is best suited to own the means of production (natural resources and infrastructural capital), both identified labour as an indispensable factor in the production of commodities, and therefore a crucial element of trade. Indeed, it seems both Smith and Marx, from opposite ends of the political spectrum, attempted to portray their theories as scientific by implicitly drawing analogies between chemical reactions and the yielding of tradable commodities by combining the means of production with the additional ingredient of human labour. ${ }^{54}$ As artificial as the analogy might sound to the postmodern ear, this "chemical equation of production" does serve to deconstruct the notion that the concept of trade can in some way be hermetically separated from the labour that is embedded in traded commodities.

In addition to this economic critique of the conceptual differentiation between trade and labour, there is a strong legal critique of the hermetic separation of the two concepts, in that international trade law is already linked to labour and many other "non-trade" concerns. As mentioned above, the drafters of the Havana Charter expressly linked labour and trade. ${ }^{55}$ Even the GATT as it stands, through Article $\mathrm{XX}(\mathrm{e})$, provides for an express general exception in relation to products produced with prison labour. Other provisions of the GATT arguably imply labour linkage exists. ${ }^{56}$ In addition, the GATT-consistent Generalised System of Preferences (GSP) regimes established by the United States and the European Union - which together account for over 35 percent of world imports ${ }^{57}$ — both allow for these Members to withdraw trade preferences upon finding a systematic violation of any of the core labour rights, ${ }^{58}$ apart from anti-discrimination, within a preference-receiver's juris-

\footnotetext{
${ }^{51}$ General Agreement on Tariffs and Trade, opened for signatures 30 October 1947, 55 UNTS 194 (entered into force 1 January 1948).

${ }^{52}$ Cited in Steve Charnovitz, Triangulating the World Trade Organization, 96 AM. J. INT'L L. 28 (2002).

${ }^{53}$ See, eg, Ruth Rikowski, Value: the Life Blood of Capitalism, 1 POL'Y FUT. EDU. 160 (2003).

${ }^{54}$ See generally ADAM SMITH, THE WEALTH OF NATIONS (first published 1776, 1976 ed), and KARL MARX, CAPITAL: A CRITIQUE OF POLITICAL ECONOMY (VOL 1) (Charles H Kerr trans, first published 1867, 1976 ed) [trans of: Das Kapital: Kritik der politischen Ökonomie].

${ }^{55}$ See above Part I.

${ }^{56}$ See, eg, Salman Bal, International Free Trade Agreements and Human Rights: Reinterpreting Article XX of the GATT, 10 MinN. J. Global Trade 62 (2001). See also Robert Howse, Back to Court After Shrimp/Turtle? Almost but not Quite Yet: India's Short Lived Challenge to Labor and Environmental Exceptions in the European Union's Generalized System of Preferences, 18 AM. U. INT'L L. REV. 1333 (2003).

${ }^{57}$ International Monetary Fund, World Economic Outlook: April 2004,

<http://www.imf.org/external/pubs/ft/weo/2004/01/data/index.htm> (last visited Sep. 29, 2004). This figure is the total combined imports of these two WTO Members, not imports under their GSP regimes.

${ }^{58}$ See above Part II
} 
diction. ${ }^{59}$ As these regimes are applied unilaterally, they are susceptible to inconsistent and politically-motivated enforcement. ${ }^{60}$ Historical and existing labour linkage therefore not only breaks down what Pahuja terms the "conceptual quarantine" between trade and labour, ${ }^{61}$ but it also demonstrates how the state of denial inherent in this dichotomy can actually undermine the multilateral trading system. ${ }^{62}$

In addition to labour itself, a whole range of concerns which are equally if not more "non-trade" than labour are now deeply embedded in trade law — behind its "facade of neutrality". ${ }^{63}$ For example, Members are now prohibited, by the Agreement on Trade-Related Investment Measures (TRIMs), ${ }^{64}$ from tying investment to local content requirements. Similarly, the Agreement on Trade-Related Intellectual Property Rights (TRIPs) ${ }^{65}$ prohibits Members from freely adopting technology. Aside from the economic impacts these instruments have on LEDCs, ${ }^{66}$ their incorporation into the WTO highlights the arbitrariness, if not the hegemonic application, of the trade/non-trade dichotomy. TRIMs and TRIPs are not focussed on reducing barriers to either trade in shares or to trade in intellectual property rights, as their names might suggest; both instruments simply establish regulatory regimes that affect trade flows. ${ }^{67}$ In fact, TRIPs may even hinder trade by granting monopoly rights over trade in protected products. ${ }^{68}$ TRIMs and TRIPs are therefore examples of mere "strategic linkage" with trade, ${ }^{69}$ and demonstrate for better or for worse the expansion of the WTO's mandate and impact beyond what might be considered "trade" in a narrow sense of the concept. ${ }^{70}$ This expansion has in turn attracted calls for the WTO to be renamed the World Economic Organization to better reflect what it has come to be. ${ }^{71}$

\footnotetext{
${ }^{59}$ Lance Compa and Jeffrey S. Vogt, Labor Rights in the Generalized System of Preferences: a 20-year Review, 22 COMP. LAB. L. \& POL'Y J. 199, 237 (2001). For example, the European Union has suspended preferences to Myanmar in response to an ILO finding into forced labour practices there: Cleveland, supra note 10 , at 134 .

${ }^{60}$ TREBILCOCK \& HOWSE, supra note 14 , at 462-3.

${ }^{61}$ Pahuja, supra note 43 , at 43.

${ }^{62}$ Cleveland, supra note 10 , at 145.

${ }^{63}$ Pahuja, supra note 43 , at 40.

${ }^{64}$ Agreement on Trade Related Aspects of Investment Measures, opened for signatures 15 April 1994, Marrakesh Agreement Establishing the World Trade Organization, Annex 1A, 1867 UNTS 187 (entered into force 1 January 1995).

${ }^{65}$ Agreement on Trade-Related Aspects of Intellectual Property Rights, opened for signatures 15 April 1994, Marrakesh Agreement Establishing the World Trade Organization, Annex 1C, 1869 UNTS 299 (entered into force 1 January 1995).

66 See, eg, Peter Costantini, What's Wrong with the WTO?, November 2001 <http://www.speakeasy.org/ peterc/wtow/> (last visited Aug. 19, 2004).

${ }^{67}$ Chantal Thomas, Should the World Trade Organization Incorporate Labor and Environmental Standards?, 61WASH. \& LEE L. REV. 347, 393-401 (2004). Thomas notes that the same applies to competition policy, which is currently on the table for incorporation into the WTO.

${ }^{68}$ See, eg, Laurinda L. Hicks and James R. Holbein, Convergence of National Intellectual Property Norms in International Trading Agreements, 12 AM. U. J. INT'L L. POL'Y 769, 771 (1997).

${ }^{69}$ David W. Leebron, Linkages, 96 AM. J. INT'L L. 5, 13 (2002).

${ }^{70}$ Adelle Blackett, Mapping the Equilibrium Line: Fundamental Principles and Rights at Work and the Interpretive Universe of the World Trade Organization, 65 SASK. L. REV. 369, 371 (2002).

${ }^{71}$ Marco C.E.J. Bronckers, More Power to the WTO?, 4 J. INT'L ECON. L.41, 64 (2001).
} 
The fact that the WTO is such a dynamic institution and has undergone rapid expansion of late means that relying on the traditional trade/non-trade dichotomy, according to which labour is classified as a "non-trade" concern, has the potential to seriously undermine the WTO's credibility. As the International Confederation of Free Trade Unions points out, "the WTO's credibility is undermined when it ensures that Mickey Mouse has more rights than the workers who make toys, because it covers trademarks but not labour standards."72 Similarly, the fact that opponents of linkage insist that labour is not a "trade" concern in the context of strengthening the enforcement of labour standards, yet in other contexts push for industrial relations reforms that enhance labour market "flexibility" in order to enhance the benefits of trade liberalisation, ${ }^{73}$ begs a questioning of the relegation of labour to the "non-trade" side of the dichotomy.

Problematising the trade/non-trade dichotomy does not require that it be thrown out altogether. After all, the dichotomy does serve to highlight that the linkage argument itself has conceptual limits. As Kennedy points out, well-meaning concepts can dominate imaginative space and crowd out other modes of understanding and acting. ${ }^{74}$ What is therefore required is a reconstruction - a reframing - of the trade/non-trade dichotomy. On this point, Garcia's scholarship is somewhat instructive. He puts forward a model whereby "trade and" debates are construed as being fundamentally questions about justice: "linkage debates are not merely disputes over the accommodation by trade policy of exogamous priorities, but rather involve disagreements at the level of normative theory, over the proper construction of $a$ just society." "75 The dichotomy can be maintained, and unwanted linkage subjects relegated to the "non-trade" side, to the extent that such subjects are unjust.

In addition to the concept of justice, human welfare, ${ }^{76}$ governance ${ }^{77}$ and market regulation (of both product and labour markets) ${ }^{78}$ have also been evoked as concepts through which the trade/non-trade dichotomy can simultaneously be maintained and bridged. As these concepts permeate both sides of the dichotomy, they demonstrate how linkages can actually be conceived as coming from within trade as

\footnotetext{
${ }^{72}$ ICFTU, cited in Elisabeth Cappuyns, Linking Labor Standards and Trade Sanctions: An Analysis of Their Current Relationship, 36 COLUM. J. TRANSNAT'L L. 659, 677 (1998).

${ }^{73}$ This tends to be the position of many employer groups: Rohini Hensman, World Trade and Workers' Rights: In Search of an Internationalist Position, 33 ANTIPODE 427, 436 (2001). It is also the position of the IMF: see, eg, Stephen S. Golub, Are International Labor Standards Needed to Prevent Social Dumping?, Finance \& Development: A Quarterly Magazine of the IMF, Dec. 1997, 21, and Anne O. Krueger, De Tocqueville's "Dangerous Moment": The Importance Of Getting Reforms Right, Speech delivered at the World Economy Lecture, University of Nottingham, (10 September 2004), <http://www.imf.org/external/np/speeches/2004/091004.htm> (last visited Sep. 30, 2004).

${ }^{74}$ DAVID KENNEDY, THE DARK SIDES OF VIRTUE: REASSESSING INTERNATIONAL HUMANITARIANISM 9 (2004).

${ }^{75}$ Garcia, supra note 1, at 426. (Emphasis added.)

${ }^{76}$ Andrew T. Guzman, Trade, Labor, Legitimacy, 91 CAL. L. REV. 885, 901 (2003).

${ }^{77}$ Thomas Cottier, Limits to International Trade: the Constitutional Challenge in Panel, The Limits of International Trade: Workers' Protection, The Environment and Other Human Rights, Proceedings of the $94^{\text {th }}$ Annual Meeting of the American Society of International Law 222 (2000).

${ }^{78}$ OZAY MEHMET, ERROL MENDES AND ROBERT Sinding, TOWARDS A FAIR GLOBAL LABOUR MARKET: AVOIDING A NEW SLAVE TRADE 197 (1999).
} 
opposed to from outside of it. ${ }^{79}$ Rather than assessing which of these concepts represents a better tool through which to understand the linkage discourse's primary conceptual differentiation, the most important thing to take out of the various critiques of the trade/non-trade dichotomy is that the rules it maintains are "contingent and a matter for political bargaining and adjustment, determined neither by economics as policy science nor by some kind of "higher law". ${ }^{80}$ This conceptual differentiation should therefore not be maintained by reference to concepts of purity and the like, but rather through an acknowledgement that linkage is complex and inherently a balancing enterprise. ${ }^{81}$

\section{B The Actors Dichotomy}

After the trade/non-trade dichotomy, the next most featured conceptual differentiation in the labour linkage discourse involves the identity of the subjects and objects of labour linkage. To this end, anti-linkage proponents often rely on the North/South dichotomy ${ }^{82}$ in order to paint labour linkage as a scheme devised by the North in order to destroy the capacity of the South to achieve its desired economic development goals. ${ }^{83}$ What is meant by the North/South dichotomy is a distinction between countries with large economies per capita against those with small ones. This is problematic for two main reasons: first, it ignores the relations within each bloc; and second, it ignores the relations within individual countries. ${ }^{84}$

After one has undergone the task of dividing countries up into the metaphorical categories of "global North" and "global South" (ie EDCs and LEDCs), the utility of the dichotomy in terms of its use within the linkage discourse begins to wane once one acknowledges the sheer diversity of labour dynamics within each category. In relation to the global North, labour relations and the social, political, economic, historical and cultural forces that shape them differ greatly between, say, the United States, Belgium and Japan. ${ }^{85}$ It is therefore conceivable that labour linkage could significantly affect trading relationships between Northern countries. Even greater diversity exists in the global South, which comprises of countries ranging from China, India and Brazil, with large, labour-intensive economies and signifi-

\footnotetext{
${ }^{79}$ Garcia, supra note 1 , at 433 .

${ }^{80}$ Robert Howse, The Boundaries of the WTO: From Politics to Technocracy — and Back Again: The Fate of the Multilateral Trading Regime, 96 AM. J. INT'L L. 94, 109 (2002).

${ }^{81}$ Blackett, supra note 70 , at 375.

${ }^{82}$ Or its many variants: Developed/Developing, First World/Third World, West/Non-West, etc.

${ }^{83}$ See, eg, Bhagwati, supra note 20. See also T. N. Srinivasan, International Trade and Labour Standards from an Economic Perspective in CHALlEnges to THE NEW WORLD TRADE ORGANIZATION (Pitou van Dijck \& Gerrit Faber eds.,1996); and Interview with Nandang Sutrisno, Sept. 14, 2004.

84 "The Third Worldist perspective gives the impression that only the advanced countries are the oppressors, neglects important differences within underdeveloped nations, and ignores the role of the locally dominant strata in these nations": JAMES H. MiTTELMAN \& MUSTAPHA KAMAL PASHA, OUT FROM UNDERDEVELOPMENT REVISITED: CHANGING GLOBAL STRUCTURES AND THE REMAKING OF THE THIRD WORLD 23 (1997), cited in Karin Mickelson, Rhetoric and Rage: Third World Voices in International Legal Discourse, 16 WIS. INT’L L. J. 353, 359 (1998).

${ }^{85}$ See generally ROGER BLANPAIN et al, COMPARATIVE LABOUR LAW AND INDUSTRIAL RELATIONS IN INDUSTRIALIZED MARKET ECONOMIES (Roger Blanpain et al eds.,7th ed. 2001).
} 
cant global political sway, to countries with small voices and small economies based almost entirely on wealth generation through agriculture. It is therefore highly likely that labour linkage could be used by Southern countries against other Southern countries, just as Indian, Malaysian, Mexican and Tanzanian unions were among those who brought a formal complaint to the ILO against the Government of Myanmar in relation to its record on forced labour. ${ }^{86}$ Labour linkage may often come to be evoked in a South-South context where one country attempts to enforce a labour standard but cannot maintain a competitive advantage, despite not being at a comparative disadvantage - the difference being that a comparative advantage comes through being more productive within the same regulatory conditions. ${ }^{87}$ For example, Nepal's efforts to eradicate child labour from its carpet manufacturing sector have put it at a competitive (but not comparative) disadvantage in relation to India, where child labour is rife in the carpet industry. ${ }^{88}$ As such, the increased focus on core labour rights ${ }^{89}$ — as opposed to more "expensive" labour standards — seriously problematises the North/South dichotomy, because "not all poor countries are in violation of core labour rights". 90 To say that labour linkage will simply give an opportunity to the North to harm the South is to falsely assume a monolithic position from Southern countries. ${ }^{91}$

The North/South dichotomy also ignores the fact that there are elements of the North within the South and vice versa. Gender inequality, racial and religious discrimination, entrenched casteism, and other forms of socio-economic disenfranchisement within many Northern and Southern countries mean that it is possible, and perhaps likely, that trade negotiators from different countries across the dichotomy have more in common with each other than with those on behalf of whom they claim to be negotiating. ${ }^{92}$ It is not uncommon for those who are disenfranchised within their respective societies at large to also be disenfranchised in trade negotiations. Indian WTO delegations, for example, have recently included businessmen as well as the traditional bureaucrats and parliamentarians, but they have not yet included NGOs. ${ }^{93}$ Similarly, the fact that many senior bureaucrats and politicians in

\footnotetext{
${ }^{86}$ See generally International Labour Office, Report of the Commission of Inquiry Appointed Under Article 26 of the Constitution of the International Labour Organization to Examine the Observance by Myanmar of the Forced Labour Convention 1930 (No. 29) (1998).

${ }^{87}$ Robert Howse and Donald Regan, The Product/Process Distinction - An Illusionary Basis for Disciplining “Unilateralism” in Trade Policy, 11 EuROPEAN J. INT'L L. 249, 281 (2000). Howse and Regan employ the term "comparative advantage" in the "efficiency-relevant sense", whereby the term is taken simply to mean the capacity of one country to produce a product at a lower cost than other countries with the same set of permitted externalities. "Competitive advantage" is thereby taken to mean the capacity of a country to produce a product at a lower cost than other countries before "legal advantages" have been taken out of the equation.

${ }^{88}$ Fields, supra note 7, at 62.

${ }^{89}$ See above Part II.

${ }^{90}$ TREBILCOCK \& HOWSE, supra note 14, at 451.

${ }^{91}$ Thomas, supra note 67, at 386.

${ }^{92}$ Benedict Kingsbury, The Tuna-Dolphin Controversy, the World Trade Organisation, and the Liberal Project to Reconceptualize International Law, 5 YEARBOOK OF INTERNATIONAL ENVIRONMENTAL LAW 1, 17 (1994), cited in TREBILCOCK \& HowSE, supra note 14, at 509.

${ }^{93}$ BHAGWATI, supra note 19 , at 104
} 
Indonesia own shares in labour-exporting companies may partly explain the Indonesian Government's failure to adequately protect Indonesian migrant workers. ${ }^{94}$

In many countries, particularly in the global South, corruption and a lack of freedom of information can exacerbate the problem of representation - within liberal democracies and dictatorships alike. ${ }^{95}$ This is evidenced by the fact that many LEDCs impose higher duties for necessities than for luxuries. ${ }^{96}$ Such practices can often be understood as symptoms of bureaucratic authoritarianism between the socalled "unholy trinity" of local elites, the military, and international capital, which can ensure that policymakers are captive to interests that do not always intersect with the interests of the majority of their fellow citizens. ${ }^{97}$ In severe cases, bureaucratic authoritarianism can result in a "hijacking" of labour law and its use as a "strategy of political control". 98 In such cases, the key motivation for breaching core labour standards may in fact be the preservation of existing social relations rather than a utilitarian desire to enhance competitive advantage through maintaining relatively lower wages. ${ }^{99}$

The fact that the North/South dichotomy overlooks relations within countries also ignores the fact that labour exploitation occurs in Northern countries, and that labour linkage may therefore be capable of holding Northern countries to account rather than simply being a tool by which they can impose unreasonable standards on Southern countries. The United States, for example, has been criticised for violating international labour law by turning a blind eye to attacks on freedom of association $^{100}$ — particularly with respect to plantation workers. ${ }^{101}$ The United States, and many other Northern countries, also systematically privilege migration law over labour law. The recent United States Supreme Court decision in Hoffman

\footnotetext{
${ }^{94}$ Marsen S. Naga, Sahkan UU Perlindungan Buruh Migran! [Ratify the Migrant Workers Protection Bill!], Kompas Interaktif, 3 November 2003 <http://www.kompas.com/kompascetak/0311/03/swara/662093.htm> (last visited Sep. 28, 2004).

${ }^{95}$ See, eg, C. Raj Kumar, Corruption and Human Rights: Promoting Transparency in Governance and the Fundamental Right to Corruption-Free Service in India, 17 COLUM. J. ASIAN L. 31 (2003).

${ }^{96}$ Saladin Al-Jurf, Citizens, National Governments, and International Financial Institutions: Changing Conceptions of Development in the 1990s, 9 TRANSNAT’L L. \& CONTEMP. PROB. 193, 196 (1999).

${ }^{97}$ Interview with Jafar Suryomenggolo, Aug. 11, 2004. See also Guillermo A. O’Donnell, Corporatism and the Question of the State in AUTHORITARIANISM AND CORPORATISM IN LATIN AMERICA 60-78 (James M. Malloy, 1977).

${ }_{98}$ Sean Cooney et al, Labour Law and Labour Market Regulation in East Asian States in LAW AND LABOUR MAR KET REgUlation IN EAST Asia 3 (Sean Cooney et al eds., 2002). See also Vedi R. HADiZ, WORKERS AND THE STATE IN NEW ORDER INDONESIA (1997).

${ }^{99}$ TREBILCOCK \& HOwSE, supra note 14, at 462.

${ }^{100}$ See generally Human Rights Watch, Unfair Advantage: Workers' Freedom of Association in the United States under International Human Rights Standards (2000)

<http://www.hrw.org/reports/2000/uslabor/> (last visited Sep. 2, 2004). The US has even been found by the ILO to have failed to uphold its obligations under a ratified forced labour convention in relation to its practice of sentencing public sector employees to forced community service work for participating in strikes, although this perhaps does not relate to a trade sector: Paul Germanotta, Forced Labor of Public Employees in the United States: A Note from the 2002 International Labor Conference, Global Policy Forum, 31 October $2002<\mathrm{http}: / / w w w . g l o b a l p o l i c y . o r g / s o c e c o n / i n e q u a l / 2002 / 1031$ ilo.htm> (last visited Aug. 10, 2004).

${ }^{101}$ See, eg, Human Rights Watch, ibid.
} 
Plastics $^{102}$ demonstrates the point at hand. By a 5:4 majority, the Court quashed a range of remedies, including back-pay, awarded by the United States National Labor Relations Board to an undocumented Mexican worker, on the basis that United States labour standards are not applicable to foreign citizens who are not authorised to work in the United States. There are, therefore, parts of the South in the North, just as there are parts of the North in the South, so resorting to an uncritical usage of the North/South dichotomy hinders effective discourse on the labour linkage question. ${ }^{103}$

Just as international law is beginning to move beyond its traditional focus on states as primary actors, ${ }^{104}$ so too must linkage discourse look beyond the state at face value and to relations both within blocs of states (ie within the North and within the South) and within countries themselves. This entails an approach which recognises that power and powerlessness, and their respective impacts on labour relations, transcend political and economic borders. ${ }^{105}$ To this end, "North-Southing" aspects of the labour linkage question can in many instances be substituted by simply "Rich-Pooring" the same aspect. ${ }^{106}$

In some instances, however, the North/South dichotomy remains instructive. ${ }^{107}$ After all, nation-states do remain, at least formally, the negotiating actors in international trade policy. Furthermore, the grounds upon which Northern (or Southern) commentators - this author included - seek to question the ability of Southern (or Northern) negotiators to act in the best interests of their fellow citizens is itself open to deconstruction. ${ }^{108}$ On many issues, the South does hold a common set of concerns, such as a collectively marginalised influence on the design of international trade institutions ${ }^{109}$ — despite voicing such concerns through a chorus that does not always blend harmoniously. ${ }^{110}$ Developing tools whereby such issues can be identi-

\footnotetext{
${ }^{102}$ Hoffman Plastic Compounds, Inc v National Labor Relations Board, 535 US 137 (2002).

${ }^{103}$ Resorting to an uncritical usage of the North/South dichotomy also hinders international humanitarianism in general: see, eg, KENNEDY, supra note 74, at 131. See also Penelope E. Andrews, Making Room for Critical Race Theory in International Law: Some Practical Pointers, 45 VILL. L. REV. 855, 876 (2000).

${ }^{104}$ See generally Balakrishnan Rajagopal, From Resistance to Renewal: The Third World, Social Movements, and the Expansion of International Institutions, 41 HARV. INT'L L. J. 529 (2000). See also Christopher McCrudden and Anne Davies, A Perspective on Trade and Labor Rights, 3 J. INT'L ECON. L.43, 61 (2000); and Obiora Chinedu Okafor, After Martyrdom: International Law, Sub-State Groups, and the Construction of Legitimate Statehood in Africa, 41 HARV. INT'L L. J. 503 (2000).

${ }^{105}$ DAVID HELD et al, GloBAL TRANSFORMATIONS: POLITICS, ECONOMICS AND CULTURE 429 (1999).

${ }^{106}$ This is presumably the actual intention of those who already make a habit of "North-Southing" international trade policy: see, eg, Joseph Weiler, Constitutional Foundations of International Economic Law, Presentation delivered at the Professor Weiler Roundtable, University of Melbourne, (29 July 2004). However, one is reminded of the Mad Hatter reprimanding Alice for assuming that meaning what one says is the same as saying what one means: LEWIS CARROLL, ALICE'S ADVENTURES IN WONDERLAND 68 (first published 1865, 30th ed. 1991).

107 Anghie thus describes the "third world" as "a problematic, anachronistic term, but one I will use nevertheless": Anthony Anghie, Time Present and Time Past: Globalization, International Financial Institutions, and the Third World, 32 N.Y.U. J. INT'L L. \& POL. 243, 243 (2000).

${ }^{108}$ Mickelson, supra note 84, at 359-60.

${ }^{109}$ TREBILCOCK \& HOWSE, supra note 14, at 367.

${ }^{110}$ Mickelson, supra note 84 , at 360.
} 
fied and incorporated into linkage discourse through the North/South dichotomy is one of the key challenges to creating a dynamic labour linkage discourse.

\section{Theological Dichotomies}

The third type of conceptual differentiation that features strongly in the labour linkage discourse might best be described as theological, in that it involves dichotomies that feature three inter-related Absolute Goods. ${ }^{111}$ First, Liberalisation is pitted against the threat of Protectionism that labour linkage allegedly poses; second, Economic Development is defined against Poverty, with labour linkage painted as being an obstacle to the former; and third, Consumption is privileged over Production, the latter of which represents labour linkage. The following discussion is not to say that Liberalisation, Economic Development and Consumption are not worthy causes; the point is that it is not constructive to exercise blind faith in relation to them. Recourse to meta-narratives can, of course, disguise power as knowledge. ${ }^{112}$ Such recourse can also hide the possibility that that these Absolute Goods may not be entirely differentiable from their Others — the Atheisms of Protectionism, Poverty and Production.

\section{$1 \quad$ Liberalisation/Protectionism}

Many anti-linkage proponents attempt to demonstrate that the "real" dispute about the merits of linkage is in fact simply a dialectic struggle between Trade and Protectionism. ${ }^{113}$ As the idea of linking trade to labour may in some cases result in one country refusing to trade with another, the idea is automatically painted as being Protectionist and a threat to the raison d'etre of the WTO: trade liberalisation. The first problem with this dichotomy is that one country refusing to trade with another does not necessarily mean that its primary motive is the protection of its own narrow interests. In fact, Protectionism may not even be a motive at all; given increasing levels of economic specialisation, in most cases the next-lowest cost exporter that has complied with a linked labour standard will be a third country rather than the sanctions-imposing country. ${ }^{114}$

The second problem with the Liberalisation/Protectionism dichotomy is a conceptual one: trade liberalisation itself, as the current trade policy insiders behind the socalled Washington Consensus understand it, ${ }^{115}$ involves a high degree of Protectionism. The World Bank, for example, often speaks of trade policy and the protection

\footnotetext{
${ }^{111}$ Or "informing myths": Pahuja, supra note 43, at 44.

${ }^{112}$ Koskenniemi, supra note 44, at 500.

${ }^{113}$ See generally Susan Tiefenbrun, Free Trade and Protectionism: The Semiotics of Seattle, 17 ARIZ. J. INT'L \& COMP. L. 257(2000). See also Bhagwati, supra note 20; and Charnovitz, supra note 50, at 832. ${ }^{114}$ TREBILCOCK \& HOWSE, supra note 14, at 447.

${ }^{115}$ See, eg, John Williamson, A Short History of the Washington Consensus, Paper presented at the From the Washington Consensus towards a New Global Governance Conference, Barcelona, (24-5 September 2004), <http://www.iie.com/publications/papers/williamson0904-2.pdf> (last visited Oct. 4, 2004).
} 
of private property rights as going hand in hand as poverty reduction strategies. ${ }^{116}$ Through TRIPs, the WTO itself is now concerned with the protection of intellectual property rights. ${ }^{117}$ Similarly, while one of the primary objectives of trade liberalisation is to reduce government subsidies, ${ }^{118}$ few if any trade Liberalists have argued for a reduction in either positive or negative regulatory subsidies (or "false labour standards"119). Positive regulatory subsidies are provided by all governments and include, for example, limited liability and the corporate form of business association, ${ }^{120}$ while repealing a law requiring air-conditioners to be installed in all shoe factories would be an example of a negative regulatory subsidy. ${ }^{121}$ In addition, neither policymakers in favour of trade liberalisation nor those in favour of labour linkage have seriously questioned the most fundamentally protective element of world markets: restrictive immigration policies. ${ }^{122}$ This may reveal hypocrisy on the part of those who advocate improvements to working conditions through labour linkage but not freedom of movement (the "yes, but not in my backyard" mentality). ${ }^{123}$ However, it also demonstrates that the Liberalisation/Protectionist dichotomy is highly conceptually problematic. The point here is that contemporary immigration policy, property laws, the corporate form and many other practices irrespective of their real merits - are Protectionist and often coexist with, or even reinforce, the power of the trade liberalisation discourse.

A third problem with analysing the labour linkage question in terms of a Liberalisation/Protectionism dichotomy is that it often morphs into the potentially misleading jobs/standards dichotomy. This dichotomy holds that any effectively enforced standards that seek to elevate working conditions will automatically act as a disincentive to international capital and therefore increase unemployment. ${ }^{124}$ This dichotomy is misleading because economists and policymakers are actually split on the issue. ${ }^{125}$ While the jobs/standards dichotomy may hold true for a broad range of

\footnotetext{
${ }^{116}$ See generally KLAUS DEININGER, LAND POLICIES FOR GROWTH AND POVERTY REDUCTION: WORLD BANK POLICY RESEARCH PAPER (2003). It is perhaps the analyses of economists such as Deininger, whether correct or not, that have led to economists being singled out among social scientists as being those most insistent about the value-free nature of their enquiry: CY GONICK, THE GREAT ECONOMIC DEBATE 148-53 (1987), cited in Pahuja, supra note 43, at 47.

${ }^{117}$ See above Part III(A).

${ }^{118}$ Paragraph 13 of the Doha Declaration, discussed above in Part II, states that “...we commit ourselves to comprehensive negotiations aimed at: substantial improvements in market access; reductions of, with a view to phasing out, all forms of export subsidies; and substantial reductions in trade-distorting domestic support..."

${ }^{119}$ Simon Deakin and Frank Wilkinson, Rights vs Efficiency? The Economic Case for Transnational Labour Standards, 3 INDUST. L. J 289, 294 (1994).

${ }^{120}$ See, eg, Zaheer, supra note 5, at 79.

${ }^{121}$ Zaheer asks, if a government grants $\$ 1$ million to one factory and then repeals a law mandating airconditioned factories which has the result of saving another factory $\$ 1$ million, why should these cases be treated differently?: Ibid 75. Similarly, Pahuja holds that "a positive subsidy is not logically distinguishable from a negative subsidy": Pahuja, supra note 43, at 50.

${ }_{122}$ TREBILCOCK \& Howse, supra note 14 , at 446. See also JAGDISH BHAGWATI, A STREAM OF WINDOWS: UNSETTLING REFLECTIONS ON TRADE, IMMIGRATION, AND DEMOCRACY 315 (1998).

${ }^{123}$ BHAGWATI, supra note 19 , at 244.

${ }^{124}$ Ibid 245.

${ }^{125}$ Kamil Ahmed, International Labor Rights - a Categorical Imperative?, 35 REVUE DE DROIT DE L'UNIVERSITE DE SHERBROOKE 145, 156 (2003).
} 
labour standards, ${ }^{126}$ recent studies into the effects of core labour rights actually reveal that these particular standards may in fact support higher productivity and job growth. These studies have not been conducted by opponents of neoLiberalism, but by multilateral financial institutions. The World Bank, for example, has found that "union density per se has a very weak association, or perhaps no association, with economic performance indicators". ${ }^{127}$ This is most likely because freedom of association can improve dialogue between workers and managers, prevent wildcat strikes, add worker input to productivity schemes and end the destabilising effects of underground unionism. ${ }^{28}$ Similarly, the Organization for Economic Co-operation and Development (OECD) has stated that enforcement of core labour rights will in no way hinder economic development, with the possible exception of the prohibition on the use of "non-hazardous" child labour. ${ }^{129}$

In addition to the World Bank and OECD studies, recent studies on Southeast Asia also call into question the jobs/standards dichotomy. These studies indicate that, in the wake of the recent financial crisis, manufacturing capital in fact moved to countries where wages were several times higher, due to factors such as security, corruption and domestic market size. ${ }^{130}$ This growing amount of literature problematising the jobs/standards dichotomy in relation to core labour rights has even prompted Nobel Prize winner and former World Bank economist Joseph Stiglitz to state that workers' rights are "key to democratic economic development". ${ }^{131} \mathrm{He}$ has also called on the Bank and related institutions to make such rights "a central focus" of their activities. ${ }^{132}$ As such, it is important to realise the limits of the jobs/standards dichotomy and that it exposes one of several serious problems with the Liberalisation/Protectionism dichotomy generally.

The fourth problem with the Liberalisation/Protectionism dichotomy as it relates to labour linkage is that both trade liberalisation and labour linkage are actually both creatures of Liberalism. The current discourse on labour linkage, with its focus on core labour rights, ${ }^{133}$ emphasises individual freedoms, not the specification of

\footnotetext{
${ }^{126}$ See, eg, J. S. Mah, Core Labour Standards and Export Performance in Developing Countries, 20 WORLD ECONOMY 773 (1997).

${ }^{127}$ TOKE AIDT AND ZAFIRIS TZANnATOS, UNiONS AND COLlECTIVE BARGAINING: ECONOMIC EFFECTS IN A GLOBAL ENVIRONMENT — A WORLD BANK DIRECTIONS IN DEVELOPMENT STUDY 11 (2002).

${ }^{128}$ See, eg, Luke L. Arnold, Towards an Understanding of Labour Law and Practice in Post-Suharto Indonesia in INDONESIA: LAW AND SOCIETY (Timothy Lindsey ed., 2d. forthcoming 2005).

${ }^{129}$ Organisation for Economic Co-operation and Development, supra note 40. See also Adelle Blackett, Whither Social Clause? Human Rights, Trade Theory and Treaty Interpretation, 31 COLUM. HUM. RTS. L. REV. 1, 31 (1999) (in most cases, core labour rights are reconcilable with market principles).

${ }^{130} \mathrm{See}$, eg, Arnold, supra note 128. Similarly, Flanagan holds that "poor labour conditions often signal low productivity or are one element of a package of national characteristics that discourage FDI inflows or inhibit export performance": Flanagan, supra note 12, at 48.

${ }^{131}$ Joseph E. Stiglitz, Democratic Development as the Fruits of Labor, Speech at the Joint Meeting of the American Economists Association and the Industrial Relations Research Association, Boston, (8 January 2000).

132 Ibid.

${ }^{133}$ See above Part II.
} 
standards resulting from the exercise of such freedoms. ${ }^{134}$ These freedoms, as with trade liberalisation, are negative rights; they are freedoms from intervention. Just as trade liberalisation's normative force comes from it articulating the right to be free from interference in the form of government-constructed barriers to trade, the current pro-labour linkage argument simply articulates the right to be free from unfair government/employer/worker intervention. ${ }^{135}$ The irony in two creatures of Liberalism being pitted against each other may be symptomatic of Liberalism's inherently contradictory nature, ${ }^{136}$ and means that a reconstruction of the Liberalisation/Protectionism dichotomy requires a questioning of the popular relegation of labour linkage to the Protectionism side of the dichotomy.

\section{Economic Development/Poverty}

Since the entrenchment of the "development paradigm" in international law and policy, as marked by then-United States President Truman's 1949 pledge to aid the "improvement and growth of underdeveloped areas", 137 "development" has primarily come to mean economic growth. ${ }^{138}$ One high-profile development consultant has even stated that "an end to poverty... inevitably means higher levels of consumption."139 This emphasis on Economic Development above all else is, of course, partly explainable by the fact that it has suited the interests of powerful countries. ${ }^{140}$ It is also reinforced by a dangerous fetish on the part of many well-meaning development actors for things that can be measured quantifiably — an "only what can be counted counts" mentality. ${ }^{141}$ This approach militates against labour linkage in that it lends support to the overly simplistic "Bhagwati Prescription": that the only way to end Poverty is to increase each country's GDP by setting an increase in trade volumes as the number one priority, above all other poverty alleviation policies. ${ }^{142}$ As discussed above, this approach is potentially incorrect in assuming, as it appears to do, that the unconditional protection of certain labour rights is incompatible with

\footnotetext{
${ }^{134}$ John Evans, The Trade Union's View on International Labour Standards in CHALLENGES TO THE NEW World TRADE ORGaniZATION 293 (Pitou van Dijck \& Gerrit Faber eds., 1996).

${ }^{135}$ The freedom not to be hindered while attempting to associate, the freedom not to be forced to work, the freedom not to be employed as a child, and the freedom not to be discriminated against: See above Part II.

${ }^{136}$ Koskenniemi, supra note 44, at 47. See also Garcia, supra note 1.

${ }^{137}$ Cited in Mark Abley, For Most, Development is a Malignant Myth, The Gazette (Montreal), Jan. 8, 1994, at 3. (Emphasis added.)

${ }^{138}$ See, eg, United Nations Development Programme, Human Development Report (1990) 104. See also Ophelia M. Yeung \& John A. Mathieson, Global Benchmarks: Comprehensive Measures of Development (1998); and Eugina McGill, Poverty and Social Analysis of Trade Agreements: A More Coherent Approach?, 27 B.C. INT'L \& COMP. L. REV. 371 (2004).

${ }^{139}$ Lawrence E. Harrison, Culture Matters, The Aust. Fin. Rev., Nov. 3, 2000 at 8.

${ }^{140}$ TREBILCOCK \& HowSE, supra note 14, at 380.

${ }^{141}$ See generally Paul Streeten, Beyond the Six Veils: Conceptualising and Measuring Poverty, $52 \mathrm{~J}$. INT'L AFFAIRS 1 (1998).

${ }^{142}$ Bhagwati states that as all developing countries, regardless of their domestic political and economic policies, have similar income distributions with respect to the bottom 30 percent of their populations, the principal strategy for raising the income of the poor is economic growth (rather than redistribution policies or enforced labour standards). The best way to achieve growth, he goes on to say, is through trade: JAGDish BhAGWATI, In DEFENSE OF GLOBALIZATION 54-64 (2004).
} 
Economic Development. ${ }^{143}$ In addition, privileging economic development at a national level, as is measured by the GDP and related indicators, ignores the fact that, even where it is successfully achieved, the rising tide of Economic Development does not necessarily lift all boats ${ }^{144}$ some boats may in fact only be lifted under the active protection of labour rights. ${ }^{145}$ Responses that argue redistribution should be left entirely to the nation-state ignore the power relations within states, as addressed above. ${ }^{146}$ Responses that instead argue - in a tone ironically similar to that of diehard Marxists - that distributional injustice occurs because the free market has never been given the chance to operate in a pure form, ${ }^{147}$ are perhaps guilty of adopting an economically autistic view of the world as ahistorical, apolitical, ungendered and without a living environment. ${ }^{148}$

Post-development theory criticises the categorisation of Economic Development as the antidote to Poverty for different but related reasons. Pointing out how the development paradigm conceives "the absence of western forms of technology... as a criterion not of difference but of underdevelopment", ${ }^{149}$ post-development theory questions the so-called "adolescence myth" that some parts of the world are more developed than others in the first place. ${ }^{150}$ As such, the development paradigm itself is criticised as a "pauperising myth". ${ }^{151}$ This position in turn has been criticised as overly romanticising the aspirations of many people in "underdeveloped" parts of the world, and therefore neglecting the fact that many popular struggles in less empowered parts of the world are actually about access to development rather than rejection of it. ${ }^{152}$ However, the post-development discourse does have the potential to make a useful contribution to the linkage discourse, particularly as it demonstrates how the development paradigm in general often ignores non-Economic aspirations.

This theme has been picked up on in the discourse relating to the emerging "right to development". This discourse urges the development paradigm to focus on consid-

\footnotetext{
${ }^{143}$ See above Part III(C)(1).

${ }^{144}$ Hilary K. Josephs, Upstairs, Trade Law; Downstairs, Labor Law, 33 GEO. WASH. INT’'L L. REV. 849, 869 (2001). This is essentially a similar argument to those that problematise the Actors Dichotomy: See above Part III(B).

${ }^{145}$ The work of Deakin and Wilkinson is instructive in this regard. They argue that "the dynamic competitiveness of economic systems" requires many inputs, an important one of which is protected labour standards: See generally Deakin and Wilkinson, supra note 119.

${ }^{146}$ See above Part III(B).

${ }^{147}$ Wouter Tims, New Standards in World Trade Agreements: Two Bridges Too Far in CHALLENGES TO THE NEW World TRADE ORGanization 312 (Pitou van Dijck \& Gerrit Faber eds., 1996).

${ }^{148}$ See, eg, Ronnie Morrison, Post-autistic Economics, Prosperity, February 2001

$<$ http://www.prosperityuk.com/prosperity/articles/pae.html> (last visited Sep. 7, 2004).

${ }^{149}$ Andy Storey, Post-Development Theory: Romanticism and Pontius Pilate Politics, 43 DEVElopment 40, 41(2000).

${ }^{150}$ Daniel K. Tarullo, Logic, Myth and the International Economic Order, 26 HARV. INT’L L. J. 533, 548 (1985).

${ }^{151}$ Post-Development Network, Annex to the Manifesto of the Post-Development Network (2002), <http://www.incommunicado.info/node/view/20> (last visited Oct. 7, 2004).

${ }^{152}$ Storey, supra note 149 , at 42.
} 
erations other than simply Economic Development, ${ }^{153}$ and thus emphasises that the promotion of the market should not be an end in itself but simply "a means of promoting human welfare and social goals." ${ }^{154}$ Article 6(2) of the Declaration on the Right to Development, ${ }^{155}$ for example, states that "equal attention... should be given to the implementation, promotion and protection of civil, political, economic, social and cultural rights". In the context of labour linkage, this approach can also highlight the fact that many labour rights are capable of making dynamic, long-term "non-labour" contributions to development. For example, restrictions imposed on the use of child labour are said to have precipitated the public education movement in Victorian England. ${ }^{156}$ This is a clear reminder that Poverty alleviation requires labour rights to be balanced with Economic Development, rather than simply circumvented by resort to an "Economic Development loophole". ${ }^{157}$ As such, a reconstruction of the Economic Development/Poverty dichotomy requires that it be applied to the labour linkage discourse in the knowledge that there are forms of poverty other than economic deprivation, and forms of development, such as the creation of dignified workplaces, other than Economic Development.

\section{Consumption/Production (Product/Process)}

A third "theological dichotomy" that frequently appears in the linkage discourse is the Consumption/Production dichotomy. This conceptual differentiation has become an entrenched aspect of GATT/WTO jurisprudence, in which it is most commonly expressed as the "product/process distinction". Before the establishment of the WTO Dispute Settlement Body (DSB), GATT panels established this dichotomy to assist with the interpretation of GATT art III - the treaty's national treatment provision. Under this Article, Members are not permitted, inter alia, to levy discriminative taxes ${ }^{158}$ or impose discriminative non-fiscal regulations ${ }^{159}$ on "like" products. This criterion of "likeness" was interpreted by the GATT Panel in the Tuna-Dolphin I case to not incorporate differences in Production processes. In that case it was held that "regulations governing the taking of dolphins incidental to the taking of tuna could not possibly affect tuna as a product." ${ }^{160}$ Although the WTO Appellate Body $(\mathrm{AB})$ has taken a more nuanced approach, it has essentially maintained this product/process dichotomy. In Japanese Alcoholic Beverages, the AB preferred a case-by-case analysis of likeness based on physical properties, end-uses,

\footnotetext{
${ }^{153}$ Anne Orford, Globalisation and the Right to Development in PEOPLES' RIGHTS 161 (Philip Alston ed., 2001).

${ }^{154}$ Anghie, supra note 107, at 250

${ }^{155}$ Declaration on the Right to Development, G.A. Res. 128 , Annex, U.N. GAOR, $41^{\text {st }}$ Sess., $97^{\text {th }}$ plen mtg, Supp No 53, U.N. Doc A/41/53 (1986).

156 TREBILCOCK \& HOWSE, supra note 14, at 449.

${ }^{157}$ Katherine Cox, The Inevitability of Nimble Fingers? Law, Development, and Child Labor, 32 VAND.

J. TRANSNAT'L L. 115, 164 (1999).

${ }^{158}$ GATT art III: 2 .

159 GATT art III: 4 .

${ }^{160}$ United States - Restriction on Imports of Tuna, GATT BISD, 39 ${ }^{\text {th }}$ Supp, 155, GATT Doc DS21/R

(1991) para [5.15] (Report of the GATT Panel, not adopted). (Emphasis added.)
} 
consumer tastes and tariff classification. ${ }^{161}$ In the Shrimp-Turtle case, what initially appears to be a decision in favour of the Production argument was in fact based on the Article XX (General Exceptions) provision, rather than on an absence of "likeness" per se. ${ }^{162}$ Similarly, in the Asbestos case, the AB found that cement-based products containing asbestos were not "like" asbestos-free cement-based products primarily due to an absence of evidence that Consumers treated them alike, ${ }^{163}$ not because Production should necessarily be taken into account when examining "likeness".

Conceiving products as distinct from the processes by which they were produced means that Consumption is privileged over Production. In Tuna-Dolphin I, for example, the United States was free to regulate the Production process of tuna within its territories, but was in breach of Article III to the extent that it attempted to regulate domestic tuna Consumption by instituting a ban on the import of tuna caught using a method that incidentally killed large amounts of dolphins. While Production is essentially ignored, ${ }^{164}$ Consumption is thus conceived as too sacred to be touched by anything other than the equally-sacred concept of Market Forces. ${ }^{165}$ This all relates to the question of labour linkage in that the product/process dichotomy has the affect of homogenising — or "abstracting", as Marx put it ${ }^{166}$ — the labour that made each product's Production possible. Due to the application of this dichotomy, a government would not be permitted to respond to collective demands by its constituent consumers that carpets produced by seven-year-old children be valued according to a basis other than the carpets" "material shells"167 alone.

The value in the product/process dichotomy is that it has served as a "fairly brightline bulwark against sliding down a slippery slope of blocking products at the

\footnotetext{
${ }^{161}$ By reference to a rather odd analogy, the AB in Japanese Alcoholic Beverages compared the concept of "likeness" to an accordion, in that its breadth does not remain constant, but rather is contingent on the "context and the circumstances that prevail in any given case to which that provision may apply": Japan - Taxes on Alcoholic Beverages, WTO Doc WT/DS8/AB/R, WT/DS10/AB/R, WT/DS11/AB/R, AB1996-2 (1996) p 21 (Report of the Appellate Body).

162 United States - Import Prohibition of Certain Shrimp and Shrimp Products, WTO Doc WT/DS58/AB/R, AB-1998-4 (1998) (Report of the Appellate Body).

163 "Thus, we find that, in particular, in the absence of any evidence concerning consumers' tastes and habits, Canada has not satisfied its burden of proving that cement-based products containing chrysotile asbestos fibres are "like" cement-based products containing PCG fibres": European Communities Measures Affecting Asbestos and Asbestos-containing Products, W.T.O. Doc WT/DS135/AB/R, AB2000-11 (2001) para [147] (Report of the Appellate Body). (Emphasis added.)

${ }^{164}$ Except, of course, in relation to one particular juridical aspect of the production process, ie intellectual property: Robert Howse, The World Trade Organization and the Protection of Workers' Rights, $3 \mathrm{~J}$. SMALL \& EMERGING BUS. L.131, 139 (1999).

${ }^{165}$ Ironically, some perceive collective choices on the part of consumers to prohibit or prefer products based on how they are produced as themselves a function of market forces. As Howse and Regan point out, "there is no economic criterion for the legitimacy of preferences": Howse and Regan, supra note 87, at 279 .

${ }^{166}$ MARX, supra note 54, at 166.

${ }^{167}$ Ibid 167.
} 
border" for purely protectionist reasons. ${ }^{168}$ For example, removing the dichotomy entirely, without replacing it with adequate safeguards, would make it a possibility, albeit an unrealistic one, for countries to prohibit certain imports on the basis that their Production did not involve child labour. As such, rather than disposing entirely of the product/process dichotomy, the labour linkage discourse would be best served by reconstructing it in a way that allows exceptions to the distinction based on actual non-protectionist policies. ${ }^{169}$

\section{Regime Dichotomies}

The fourth kind of conceptual differentiation that appears frequently in the labour linkage discourse involves dichotomies relating to the question of what types of regimes are best suited to the regulation of workplace relations and the labour market. These dichotomies can therefore be termed "regime dichotomies". The three major "regime dichotomies" identifiable in the labour linkage discourse are universalist/relativist, WTO/ILO and welfare/sanctions. ${ }^{170}$ These will be analysed in turn.

\section{$1 \quad$ Universalist/relativist}

The argument that labour linkage harms the competitive advantage of LEDCs, because it entails the imposition of international standards that are not compatible with domestic contexts, relies on the notion that universal standards are distinct from standards that recognise some degree of relativity. ${ }^{171}$ Having established this universalist/relativist dichotomy, anti-linkage proponents are therefore able to argue that certain countries or regions have the right to create their own standards with respect to the regulation of employment relationships and the labour market, and that it is not possible for them to do this within a framework of international standards. ${ }^{172}$ Aside from the problems relating to who is creating standards for who in such a scenario, ${ }^{173}$ this line of argument ignores the fact that an international labour regulation regime can be simultaneously universal and relative.

\footnotetext{
${ }^{168}$ Remarks by John H. Jackson in Panel, The Limits of International Trade: Workers' Protection, The Environment and Other Human Rights, Proceedings of the $94^{\text {th }}$ Annual Meeting of the American Society of International Law 224 (2000).

${ }^{169}$ This could perhaps be achieved through the addition of an "Article XX chapeau"-type clause: Howse and Regan, supra note 87 , at 279-85.

${ }^{170}$ Amongst those who are in favour of labour linkage, there is yet another regime dichotomy involving the question of what mode - legislative or judicial - linkage should take. The case for legislative linkage is well articulated in Guzman, supra note 76; and Jose E. Alvarez, How Not to Link: Institutional Conundrums of an Expanded Trade Regime, 7 WIDENER L. SYMP. 1 (2001). On the case for judicial linkage, see Adelle Blackett, supra note 129; and Josephs, supra note 144. A discussion of this "internal regime dichotomy" is, however, beyond the scope of this paper.

${ }^{171}$ This line of reasoning seems to have influenced the Panel in Shrimp-Turtle case, discussed above, at first instance: see United States - Import Prohibition of Certain Shrimp and Shrimp Products, WTO Doc WT/DS58/R, 98-1710 (1998) (Report of the Panel).

${ }^{172}$ See, eg, Mohamad, supra note 17 , at 6.

${ }^{173}$ See discussion of the "actors dichotomy", above Part III(B).
} 
Different states can, and do, implement the normative content of universal standards in different ways; universalism is not absolutism. ${ }^{174}$ For example, in a study of seven East Asian countries, Cooney et al found that all had adopted international labour standards to some extent, yet these standards in turn adopted a unique character and impact in each jurisdiction. ${ }^{175} \mathrm{By}$ virtue of the fact that legally "transplanted" concepts may be understood differently by the bureaucracy, the judiciary, the legal profession and the public in each country, it may actually be inevitable that each jurisdiction will adopt universal standards in a relativist way. ${ }^{176}$ In addition, universal standards themselves can allow for relativity. The ILO's Minimum Age Convention, for example, allows countries "whose economy and educational facilities are insufficiently developed" to substitute lower minimum ages than those ordinarily required. ${ }^{177}$ Similarly, the European Social Charter Committee of Experts has defined a "decent standard of living" not by reference to an absolute wage, but by the universal standard of 68 percent of a nation's average wage, thereby allowing for differences according to relative economic development. ${ }^{178}$ Such examples highlight the misconception that universal and relative standards are necessarily mutually exclusive. The labour linkage model discussed below in Part IV thus attempts to reconstruct the universalist/relativist dichotomy so that it incorporates this knowledge.

\section{$2 \quad$ WTO/LO}

A corollary of the trade/non-trade dichotomy discussed above ${ }^{179}$ is argument within the labour linkage discourse about which institution/institutions is/are best suited to dealing with international labour standards. Those opposed to labour linkage often structure their arguments on this point around a WTO/ILO dichotomy. The International Labour Organization, it is argued, is the institution best suited to dealing with labour, while the World Trade Organization is best suited to dealing with trade. ${ }^{180}$ As such, efficiency demands that the twain shall never meet - other than through "mutual consultation" aimed at ensuring "consistency of actions". ${ }^{181}$ However, the "you-cannot-kill-two-birds-with-one-stone"182 understanding of the role of institutions in achieving social goals is fast becoming outdated; as Sen points out, "the idea of doing one thing at a time is, of course, full of charm... but it isn't a great

\footnotetext{
${ }^{174}$ TREBILCOCK \& HOWSE, supra note 14 , at 443.

175 See generally LAW AND LABOUR MARKET REGULATION IN EAST ASIA (Sean Cooney et al eds., 2002).

${ }^{176}$ See, eg, Cooney et al, supra note 98 , at 13.

${ }^{177}$ ILO Convention No 138 concerning the Minimum Age for Admission to Employment, opened for signatures 26 June 1973, 1015 UNTS 297, art 2(4) (entered into force 19 June 1976).

${ }^{178}$ Cleveland, supra note 10, at 157.

${ }^{179}$ See Part III(A).

${ }^{180}$ This was the position put forward in the Singapore Ministerial Declaration and affirmed in the Doha Ministerial Declaration: See above Part II.

${ }^{181}$ Srinivasan, supra note 83 , at 221.

182 "Linkage is like trying to kill two birds with one stone, so we need another stone": CUTS Centre for International Trade, Economics and Environment, supra note 49.
} 
guide to practical policy". ${ }^{183}$ Instead, the idea that certain issues, like labour, can and should come within the purview of more than one institution is gaining currency within international social institutions. This is demonstrated, for example, by the increasing popularity of the "mainstreaming" paradigm within organisations such as the ILO — with extensive experience in working for social goals. ${ }^{184}$

The ILO and the WTO are very different organisations; they have different mandates and different strategies for implementing them. However, rather than being a reason why labour should be assigned to one and not the other, this is a reason why it should be addressed by both. While the ILO's modus operandi is to achieve desired outcomes through social dialogue and the "carrots" of technical assistance and development aid, the WTO is now increasingly making use of the DSB and resorting to the "stick" of authorised trade sanctions. ${ }^{185}$ Due to the fact that each dispute in relation to labour will have its own context and therefore demand a unique remedy, it is likely that a combination of these hard/soft approaches will achieve the best overall outcomes. ${ }^{186}$ After all, dual- or multi-organisational approaches are already a feature of the WTO. Dispute settlement, for example, often involves expert advice from international organisations in relation to various standards. ${ }^{187}$ Formal procedures could be put in place for the ILO to serve as an expert witness, compliance monitor and technical assistant in labour-related WTO disputes and their follow-ups. ${ }^{188}$ The fact that the ILO's Constitution grants it the authority to issue trade sanctions, ${ }^{189}$ while the WTO has an established framework for managing such sanctions, is perhaps a strong enough a mandate for this. ${ }^{190}$

\section{$3 \quad$ Welfare/sanctions}

Several commentators claim not to be against the idea of international labour standards per se as much as the notion that they should be enforced by recourse to sanctions. ${ }^{191}$ Their argument is often that on "moral causes" such as the treatment of labour, "a good tongue-lashing... is more likely to work today than a bite."192 This argument partly rests on the carrots/sticks dichotomy discussed above. ${ }^{193}$ It also

\footnotetext{
${ }^{183}$ Amartya Sen, What is the Role of Legal and Judicial Reform in the Development Process?, Paper presented to the World Bank Legal Conference, Washington, (5 June 2000) 3.

${ }^{184}$ See, eg, International Labour Office, ILO Action Plan on Gender Equality and Gender Mainstreaming (2001). See also McGill, supra note 137, at 396.

${ }^{185}$ See, eg, Flanagan, supra note 12, at 19. For a discussion on the impact of WTO sanctions, See below Part III(D)(3).

${ }^{186}$ Cleveland, supra note 10, at 151. See also Katherine van Wezel Stone, To the Yukon and Beyond: Local Laborers in a Global Labor Market, 3 J. SMALL \& EMERGING BUS. L. 93 (1999).

${ }^{187}$ For example, GATT/WTO Panels frequently consult the World Health Organization: see, eg, Thailand - Restrictions on Importation of and Internal Taxes on Cigarettes, BISD, 37th Supp, 200, GATT Doc DS10/R (1990) para [27] (Report of the GATT Panel, adopted 7 November 1990).

${ }^{188}$ Zaheer, supra note 5, at 100.

${ }^{189}$ Constitution of the International Labour Organization (1919) art 33.

${ }^{190}$ See, eg, Zaheer, supra note 5, at 84. See also Bal, supra note 56, at 67; and Howse, supra note 164, at 134.

${ }^{191}$ See, eg, Bhagwati, supra note 20. See also Sutrisno, supra note 83.

192 BHAGWATI, supra note 19, at 250.

${ }^{193}$ See above Part III(D)(2).
} 
relies on another dichotomy, based on labour being an irrational "moral cause", as opposed to the amoral, scientific pursuit of trade. It is therefore acceptable that violations of trade agreements - themselves replete with language privileging the amoral and scientific ${ }^{194}$ — be met with an authorisation of sanctions, while the authorisation of sanctions for the violation of trade-related labour standards is construed as such an imprecise exercise that it would put innocent people's welfare at stake.

To be sure, many of the claims that WTO-authorised trade sanctions will hurt those they are intended to protect are well founded. Where sanctions are authorised against an LEDC, for example, it may deprive it of the trade revenue required to improve its labour conditions. ${ }^{195}$ Even where an LEDC is able to bring a successful case, ${ }^{196}$ the remedy of authorised sanctions may not be attractive as this may deprive it of valuable imports and make no real impact on the target. ${ }^{197}$

Notwithstanding these significant concerns, the welfare/sanctions dichotomy remains problematic. First, the claim that current trade agreements are more rational than a mechanism for labour linkage is in defiance of the fact that many current GATT/WTO Agreements actually embrace the mystery, value judgments and irrationality they claim to exclude. ${ }^{198}$ If one accepts that it is possible for a rational application of sanctions under such Agreements, one should also consider the possibility that sanctions in relation to "moral causes" may be equally as rational. ${ }^{199}$

Second, it is unlikely that sanctions will be authorised unless gross violations of labour standards have occurred. ${ }^{200}$ Rather, it may be the case that the real value of sanctions is that they can lurk as a potential threat to would-be violators as they bargain in the shadow of the law. ${ }^{201}$ As anyone who has attended a mediation session prior to a civil trial would be aware, no party will bargain in good faith without knowing that going to trial is a possibility (albeit improbable), even where all parties may be convinced that going to trial is the most undesirable outcome. In the

\footnotetext{
${ }^{194}$ Anne Orford, Trade, Human Rights and the Economy of Sacrifice, Working Paper No 03/04, Jean Monnet Program, New York University School of Law, 2004, 20.

${ }^{195}$ Sutrisno, supra note 83.

${ }^{196}$ There are a number of structural obstacles militating against this in the case of an LEDC bringing a case against an EDC. These include the ability of powerful countries to use their political and economic weight to discourage claims, the inability of many LEDCs to have access to a well-resourced legal team, and the difficulty for LEDCs in collecting data capable of being used as credible evidence: see, eg, Marc L. Busch and Eric Reinhardt, Bargaining in the Shadow of the Law: Early Settlement in GATT/WTO Disputes, 24 FORDHAM INT'L L. J. 158 (2000).

${ }^{200}$ If it is any indication, the ILO has only recommended sanctions on one occasion in its 85 -year history: see International Labour Office, Report of the Commission of Inquiry, supra note 86, and the adoption of its recommendations at the $279^{\text {th }}$ Session of the Governing Body of the International Labour Organization, November 2000.

${ }^{201}$ See, eg, Daniel W. Drezner, The Hidden Hand of Economic Coercion, Paper presented at the Forth Meeting of the European Consortium on Political Research's Standing Group on International Relations, Canterbury, (6-8 September 2001).
} 
same way, without the threat of sanctions there may be an incentive for countries to agree on unattainable or unworkable forms of labour linkage, and/or for the empowered elements of those countries ${ }^{202}$ to give lip service only to the implementation of linked standards.

The third problem with the welfare/sanctions dichotomy is that although sanctions may harm some innocent people, their employment may represent the lesser of two evils. ${ }^{203}$ Take for example the concept of imprisonment, the most severe criminal penalty in most local jurisdictions where capital punishment does not apply. In most cases, imprisoning an individual will involve causing significant harm to innocent individuals - the criminal's children, partner, parents, etc. The fact that such harm occurs is a good reason to make the process for determining guilt as robust as possible, to minimise the harm suffered by third parties, and to focus policy-making energy on macro-level crime prevention (eg through reducing unemployment, enabling greater access to education, etc). However, even ardent civil libertarians would be unlikely to support the abolition of imprisonment in all cases. It may be harsh, but the alternatives for both the innocent individuals and for society at large may be even worse without it. In some instances, this may be the case with sanctions.

It is common knowledge that "sanctions", in both bilateral and multilateral contexts, is a dirty word among most international legal scholars, and perhaps deservedly so. The UN sanctions on Iraq resulted in the death of an estimated two million civilians $^{204}$ - forty percent of them under five years of age $\mathrm{e}^{205}$ - and in doing so reinforced a former UN Secretary-General's statement that sanctions are "blunt instruments". ${ }^{206}$ Moreover, the sanctions on Iraq were unsuccessful in achieving their desired outcome, and perhaps even frustrated the situation.

For all the problems associated with them, however, international sanctions are also dynamic instruments. The current trend within the United Nations Security Council, for example, is a move towards better-honed international sanctions — with indications of success in some cases. These include the travel bans that were placed on the Milosevic clique in the former Yugoslavia, ${ }^{207}$ the airspace restrictions placed on

\footnotetext{
${ }^{202}$ See discussion of the actors dichotomy, above Part III(B).

${ }^{203}$ See generally David A. Baldwin, The Sanctions Debate and the Logic of Choice, 24 INT'L SECURITY 80 (1999).

${ }^{204}$ George E. Bisharat, Facing Tyranny with Justice: Alternatives to War in the Confrontation with Iraq, 7 J. GENDER, RACE AND JUSTICE 1, 26 (2003).

${ }^{205}$ GeOFF SimONS, THE SCOURGING OF IRAQ 223 (2d ed. 1998).

${ }^{206}$ Boutros Boutros-Ghali, Supplement to an Agenda for Peace: Position Paper of the Secretary-General on the Occasion of the Fiftieth Anniversary of the United Nations, [70], UN Doc A/50/60 (1995).

${ }^{207}$ See, eg, Gary Hufbauer and Barbara Oegg, Targeted Sanctions: A Policy Alternative?, Paper presented at the Institute for International Economics Symposium on Sanctions Reform in Asia and the World, Washington, (23 February 2000) <http://www.iie.com/publications/papers/hufbauer0200.htm> (last visited May 20, 2004).
} 
Lybia, ${ }^{208}$ and the strict certification regime imposed to restrict profit-making from "conflict diamonds" in Africa. ${ }^{209}$

There is no reason why the WTO cannot develop kinds of sanctions that involve less "bluntness" than sanctions as we have currently come to understand them. Trebilcock and Howse suggest, for example, that sanctions could go beyond even sectors of the economy, and instead apply only to particular businesses within a given sector. ${ }^{210}$ Given these possibilities, it is easier to imagine a situation where the potential harm caused by sanctions would be outweighed by the harm that would result from not applying them. In such circumstances, however rare, it would be prudent to question the welfare/sanctions dichotomy. After all, decision-makers do not have the option of criticising every avenue of action or inaction with which they are presented — when something must be done, sanctions may be the best option. ${ }^{21}$

\section{Moving Beyond Established Conceptual Differentiations: a Cross-cutting LinKage MODEL?}

The above discussion has examined some of the key conceptual differentiations featured in the labour linkage discourse, and revealed several of the "hidden contradictions" and "unconscious desires" that exist within them. ${ }^{212}$ It is therefore hoped that such revelations will provide some "new space" between international trade law and labour rights discourse for further debate and decision on the issue of labour linkage. ${ }^{213}$ This next Part aims to build on these revelations so as to suggest a labour linkage model that cuts across some of the traditional conceptual differentiations that have brought the discourse to a stalemate. In no way do I intend this to be understood as a comprehensive and coherent solution to the labour linkage issue; ${ }^{214}$ the model I suggest is designed to demonstrate how the discourse can continue without constant reference to the traditional conceptual differentiations discussed above. In all likelihood, this model will in turn be based on conceptual differentiations which, in turn, need to be put to further criticism: "the critical process must continue". ${ }^{215}$ After all, justice may be an "experience of the impossible". ${ }^{216}$ How-

\footnotetext{
208 See, eg, Flynt Leverett, Why Libya Gave Up on the Bomb, New York Times, Jan. 23, 2004 <http://www.mtholyoke.edu/acad/intrel/bush/libya.htm> (last visited May 20, 2004).

${ }^{209}$ Resolution on Angola, S.C. Res. 1176, U.N. SCOR, 53 ${ }^{\text {rd }}$ Sess., $3894^{\text {th }}$ mtg, U.N. Doc S/RES/1176 (1998); and Resolution on the Situation in Sierra Leone, S.C. Res. 1306, U.N. SCOR, $55^{\text {th }}$ Sess., $4168^{\text {th }}$ mtg., U.N. Doc S/RES/1306 (2000).

${ }^{210}$ See, eg, TREBILCOCK \& HOWSE, supra note 14, at 448.

${ }^{211}$ Hence Baldwin is critical of the number of studies that focus on the low success rate of sanctions without considering the impact of policy alternatives: See generally Baldwin, supra note 203.

${ }^{212}$ Martii Koskenniemi, What Should International Lawyers Learn from Karl Marx?, 17 LEIDEN J. INT'L L. 229, 241(2004).

${ }^{213}$ The idea of creating new space for linkage discourse is discussed at length in Pahuja, supra note 43.

${ }^{214}$ If I had that intention, I would have at least made an attempt — as Yablon puts it — to jazz the model up with a lot more references to theoretical debates with which neither of us are familiar, and articles you have never read and I have only skimmed: See generally Charles Yablon, Stupid Lawyer Tricks: An Essay on Discovery Abuse, 96 COLUM. L. REV. 1618, 1619 (1996).

${ }^{215}$ Koskenniemi, supra note 44, at 487.
} 
ever, maintaining a dynamic discourse may be a step towards it. In fact, putting forward new models for labour linkage may in itself be a form of action, as those who seek to derail labour linkage may find themselves making serious attempts to improve labour conditions so as to demonstrate that labour linkage is not necessary. $^{217}$

\section{A A Suggested Linkage Model}

The model for linkage I put forward builds on the international community's increased focus on core labour rights. ${ }^{218}$ It involves, controversially, the use of sanctions - in a very limited set of circumstances. Under this model, the four "fundamental rights" identified by the ILO - freedom of association, freedom from forced labour, freedom from child labour and freedom from discrimination would be made subject to a "comply or explain-and-enforce" mechanism in export sectors. Individual countries would have the option of electing to join either a "comply" scheme or an "explain-and-enforce" scheme. Electing the latter scheme would not, of course, absolve the country of its obligations to the ILO under the ILO Declaration; it would simply mean that the enforcement of those obligations would be outside the WTO's jurisdiction.

Where a country has joined the "comply" scheme but is found by the DSB to have permitted or caused any of the rights to not be enforced in its export sector, by reason other than institutional incapacity, other countries would be authorised to impose sanctions on it. Where a country elects the "explain-and-enforce" scheme, it has two obligations: first, it must submit an explanation to the WTO Secretariat as to why it has not joined the "comply" scheme; second, it must create and enforce its own laws in relation to the core labour rights within its export sector. This first obligation is essentially similar to existing regimes in various stock exchanges, whereby listed corporations are required to explain any deviation from best practice guidelines. $^{219}$ The second obligation on countries that "opt-out" of WTO enforcement of core labour rights is based on the North American Agreement on Labor Cooperation (NAALC), ${ }^{220}$ which includes an "enforce your own laws" provision, the breach of which can attract sanctions in relation to occupational health and safety, child labour and minimum wages. ${ }^{221}$ To combat the privileging of migration

\footnotetext{
${ }^{216}$ Jacques Derrida, Force of Law: The "Mystical Foundation of Authority" (trans Mary Quaintance) in DeCONSTRUCTION AND THE POSSIBILITY OF JUSTICE 16 (Drucilla Cornell et al eds.,1992) [trans of: Force de loi: "Fondement mystique de l'autorité"].

${ }^{217}$ Mehmet et al, supra note 78 , at 82.

${ }^{218}$ See above Part II.

${ }^{219}$ See, eg, Australian Stock Exchange Corporate Governance Council, Principles of Good Governance and Best Practice Recommendations (2003). See also Commonwealth of Australia, Royal Commission into the Failure of HIH Insurance, Final Report (2003).

${ }^{220}$ North American Agreement on Labor Cooperation, 8 September 1993, United States-Canada-Mexico, 32 ILM 1499 (entered into force 1 January 1994).

${ }^{221}$ NAALC art 29. Parties are also under an obligation to effectively enforce all of their own labour laws and ensure they provide for "high labo[u]r standards" (arts 2-3), but non-enforcement of laws outside the scope of occupational health and safety, child labour and minimum wages is not subject to arbitration or sanctions.
} 
laws over labour laws, particularly in EDCs, ${ }^{222}$ the "enforce your own laws" provision could include a requirement that non-citizens be afforded the same protection as citizens with respect to the fundamental rights. ${ }^{223}$ Not complying with these obligations would also attract authorised sanctions.

A fair and workable labour linkage model also requires some reform to WTO dispute settlement procedures, remedies and the Secretariat. Due to the evidentiary burden faced by some countries in obtaining information about foreign labour laws and their (non)enforcement, ${ }^{224}$ ILO findings should be deemed to be sufficient evidence. Unlike under the NAALC, expedited proceedings should be permitted where, for example, there is a linkage complaint involving a large disparity between the legal resources available to the parties. ${ }^{225}$

The model would include authorised sanctions for the reasons discussed above, ${ }^{226}$ in particular the notions that in some cases sanctions may be a "lesser evil" or may be necessary in order to encourage parties to bargain in good faith. In such cases, so as to avoid punishing innocent businesses, sanctions in response to linkage should, where possible, be targeted at individual enterprises rather than entire sectors or countries. $^{227}$ In addition, a test could be included whereby the onus would lie with the sanctioning country to demonstrate that the net human harm caused by the sanctions would be less than the harm caused by continued non-enforcement. Where the country authorised to implement a sanction against another is an LEDC and can demonstrate that sanctions will tangibly harm its own economic development, it should be entitled to a different remedy. This could include a right to suspend the violating country's WTO voting rights or DSB-access rights, to receive mandatory compensation, or to trade its authorisation to a country that is able to carry it out. These stringent requirements for the authorisation of trade sanctions and other penalties mean that they would rarely if ever be used. This does not mean, however, that they would be useless; they would play a key role in enforcing certain standards by remaining a residual threat.

Changes to the WTO Secretariat could include the establishment of a framework through which workers and employers can enjoy permanent observer status at WTO negotiations. This would address the problems associated with these groups having to rely on ad hoc invitations from their respective governments. ${ }^{228}$ Another change

\footnotetext{
${ }^{222}$ See above Part III(B).

${ }^{223} \mathrm{Cf}$ Cleveland, who has put forward the idea that the right to equal treatment for migrant workers should exist across the board rather than simply in respect to fundamental rights: Cleveland, supra note 10, at 158-9. See also below Part IV(B)(2).

${ }^{224}$ Karen Vossler Champion, Who Pays for Free Trade? The Dilemma of Free Trade and International Labor Standards, 22 N.C. J. INT'L L. \& COM. REG. 181, 235 (1996).

${ }^{225}$ See, eg, Zaheer, supra note 5, at 102.

${ }^{226}$ See above Part III(D)(3).

${ }^{227}$ Ibid. At this point, the labour rights approach seems to depart from the traditional human rights approach, the latter of which has in the past tended to foreground harm done explicitly by governments: KENNEDY, supra note 74, at 9.

${ }^{228}$ This seems to concur with the recent recommendation of the ILO World Commission on the Social Dimension of Globalization that the WTO establish "formal consultation structures" in order to receive
} 
to the Secretariat could be the establishment of a Working Group on Trade-Related Aspects of People Movement, which would be charged with investigating policy solutions that deal with the imbalance brought about by the simultaneous liberalisation of the movement of goods and deliberalisation of the movement of natural persons. $^{229}$

The most important feature of the proposed model is that it allows for a flexible approach to labour linkage yet seeks to firmly entrench the rule of law at an international level in relation to what have been credibly identified as core labour rights. Key difficulties will lie in defining the standard of enforcement required, ${ }^{230}$ assessing when non-enforcement can be attributable to institutional deficiency rather than an absence of political will, ${ }^{231}$ and determining the kind of situations where sanctions will result in less harm than non-enforcement. However, problems involving standard setting, the adducing of motives, and the determination of appropriate penalties are the very essence of law. As with other jurisdictions, ${ }^{232}$ solutions to such problems can be found through the political process and through jurisprudence, the latter of which in this instance may be able to draw on the "margin of appreciation" doctrine developed by the European Court of Human Rights. ${ }^{233}$

A further problem will arise by virtue of the fact that a great deal of labour legislation in LEDCs can be best described as "aspirational", in that it "puts forth a vision of what reality should be". ${ }^{234}$ Forcing these countries to enforce their laws, critics hold, thereby robs them of much-needed "flexibility". ${ }^{235}$ Without seeking to encourage the kind of legal triumphalism apparent in many EDCs, ${ }^{236}$ it is important to address this criticism by pointing to the importance of the rule of law for both economic development and the creation of sustainable freedom in the workplace and labour market. $^{237}$

policy input from workers: ILO World Commission on the Social Dimension of Globalization, supra note 36 , at 124 .

${ }^{229}$ See, eg, United Nations, Report of the High-Level Panel on Financing for Development 15 (2001) (calling for investigation into an international agreement on the movement of natural persons). See also BHAGWATI, supra note 122, at 315 (calling for the establishment of a World Migration Organisation).

${ }^{230}$ See e eg, BHAGWATI, supra note 19 , at 247.

${ }^{231}$ Fields, supra note 7 , at 72.

${ }^{232}$ And, in fact, with the intellectual property linkage within the WTO itself, which came out of a regime administered by the World Intellectual Property Organization that lacked both a consensus about fundamental standards and effective enforcement mechanisms: Thomas, supra note 67, at 398.

${ }^{233}$ Under this doctrine, "national governments are given a certain degree of discretion regarding the specific manner in which they implement European Convention rights": Douglas Lee Donoho, Autonomy, Self-Governance, and the Margin of Appreciation: Developing a Jurisprudence of Diversity within Universal Human Rights, 15 EMORY INT'L L. REV. 391, 451 (2001). See also Eyal Benvenisti, Margin of Appreciation, Consensus, and Universal Standards, 31 N.Y.U. J. INT'L L. \& POL. 843 (1999).

${ }^{234}$ Matei Mihalca, Rule of Law in China, Rediff.Com, 23 February 2004

<http://www.rediff.com/money/2004/feb/23guest2.htm> (last visited Aug. 24, 2004).

${ }^{235}$ BHAGWATI, supra note 19, at 249.

${ }^{236}$ See generally Stephen J. Toope, Legal and Judicial Reform Through Development Assistance: Some Lessons, 48 MCGILL L. J. 357 (2003).

${ }^{237}$ See generally Todd J. Zywicki, The Rule of Law, Freedom, and Prosperity, 10 SuP. CT. ECO. REV. 1 (2002). 
While it is important that countries have flexibility in determining the content of their laws, the rule of law, when understood as authority being carried out "in accordance with known and objective legal principles", 238 demands an abandonment of "flexibility" as to whether or not a law should be applied at all. This kind of "flexibility" simply gives the state the prerogative to conduct discriminatory law enforcement, thus serving to perpetuate existing power relations and ultimately working against both economic growth and labour rights. As such, the ILO has stressed the "need for a renewed role for the state, built on the rule of law and democratic institutions". ${ }^{239}$ Across the globe, it is only in this way that law, and labour law in particular, will have any chance of significantly influencing other social systems, such as the state or the market. ${ }^{240}$

\section{B A Challenge to Traditional Conceptual Differentiations?}

Potentially the most biting of critiques of this model is its lack of political support. However, to make such a critique is to misunderstand my intention behind putting forth the model. In putting forward the above model, I do not intend to garner political support but to make room for political decisions ${ }^{241}$ - be they judicial or legislative. ${ }^{242}$ The amount of room created may be a function of the extent to which the model prompts ways of thinking outside the traditional dichotomies. As such, the discussion below turns to this point.

\section{The Conceptual Dichotomy}

The suggested labour linkage model challenges the conceptual dichotomy ${ }^{243}$ in several ways. Once one begins to talk less about the abstract and more about pragmatic policy options, notions of purity and contamination become more difficult to sustain, because it becomes possible to imagine linkage as being part of trade itself. ${ }^{244}$ Suggestions for reform also demonstrate the fundamentally political nature of trade regulation; it becomes clear to see that what is within and outside trade is dynamic, and determined by decisions of negotiators, adjudicators and commentators rather than by divine order. ${ }^{245}$ (In this regard, further analysis of the trade/nontrade dichotomy could learn from feminist critiques of how the public/private dichotomy has been presented as immutable, apolitical and pre-existing, in order to

\footnotetext{
${ }^{238}$ United Kingdom Overseas Development Administration, Law, Good Government and Development (1996) 3, cited in Toope, supra note 236, at 369.

${ }^{239}$ ILO World Commission on the Social Dimension of Globalization, supra note 36, at 14.

${ }^{240}$ For a discussion of the relationship between labour law and other social systems, See generally Sean Cooney and Richard Mitchell, What is Labour Law Doing in East Asia? in LAW AND LABOUR MARKET REGULATION IN EAST ASIA (Sean Cooney et al eds., 2002).

${ }^{241}$ See generally Koskenniemi, supra note 212.

${ }^{242}$ See supra note 170 and accompanying text.

${ }^{243}$ See above Part III(A).

${ }^{244}$ Or perhaps as intersecting with it rather than simply running parallel to it: Pahuja, supra note 43, at 40.

${ }^{245}$ See generally Koskenniemi, supra note 212.
} 
mask the gender dimensions of power relations. ${ }^{246}$ ) Importantly, linkage proposals also demonstrate the limits of linkage. For example, the above model covers only four "core rights", while other workplace and labour market standards are left to be pursued by means outside the scope of contemporary trade regulation. Trade and labour can thus each be linked without being fully consumed by the other. ${ }^{247}$

The notion that trade and labour are neither mutually exclusive nor mutually inclusive is further demonstrated by the suggested model's application to export sectors only. This provides a clear conceptual link between trade and labour: people who produce goods and services to be traded internationally are those whose labour rights should be protected by international trade law. There may be significant difficulties involved with determining this scope: what happens, for example, if Nike respects the core rights of those who produce Nike shoes for export, but those who are engaged by sub-sub-contractors to provide the catering services to a Nike factory are denied, say, the right to associate? The answer will inevitably involve judgement and a degree of artificiality, and those who fall outside this scope may suffer - at least in the short-term. ${ }^{248}$ However, the very possibility that it may be politically plausible to distinguish a group of people as workers involved in trade from those not involved in trade, is capable of significantly disturbing the trade/non-trade dichotomy in relation to labour linkage and therefore creating room for political decisions.

\section{The Actors Dichotomy}

The proposed model deals to some extent with the problems posed by the North/South dichotomy. ${ }^{249}$ The idea that the governments of countries have primary responsibility for the welfare of their constituent populations is preserved, in that states are given the right to elect an enforcement regime. However, the authority of the state is checked by the requirement that it clarifies why (through the explanation mechanism) and how (through its domestic laws) it has decided to place itself outside the WTO enforcement of standards around which a broad international consensus exists. ${ }^{250}$ This check may therefore create a situation in which states and their beneficiaries are made more accountable to both domestic and international stakeholders. These stakeholders might include unions, industry groups, farmers' associations, aid organisations and of course other states - from both within and outside the same North/South bloc. ${ }^{251}$ The concept of targeted sanctions ${ }^{252}$ even

\footnotetext{
${ }^{246}$ See generally Pahuja, supra note 43.

${ }^{247}$ This should come as a relief to both those who seek to keep trade "pure" and also those, such as Pahuja, who support linkage but caution against an "add human rights to trade and stir" approach: Ibid 41.

${ }^{248}$ However, in the long-term the capacity of the export sector to establish standards for domestic production may neutralise this.

${ }^{249}$ See above Part III(B).

${ }^{250}$ And which, as far as the ILO is concerned, they are bound to implement by virtue of the ILO Declaration: See above Part II.

${ }^{251}$ Harry Arthurs, Reinventing Labor Law for the Global Economy: the Benjamin Aaron Lecture, 22 BERKELEY J. EMP. \& LAB. L. 271, 287 (2001)

${ }^{252}$ See above Part III(D)(3).
} 
opens up the possibility that one state may sanction a producer, or a foreign subsidiary of a producer, that is owned by its own citizens. Many of the complaints lodged against Mexico under the NAALC, for example, have actually been in response to practices by United States companies and their subsidiaries run by Mexican elites. ${ }^{253}$

The model also deals with an anomaly within the North/South framework: migrant workers. For the most part, migrant workers are "non-actors" in the North/South dichotomy, as they fall outside what has come to be the primary responsibility of states: protecting their own citizens within their own borders. ${ }^{254}$ However, the model does not propose to compel states to afford the same rights across the board to migrant workers as they afford to their own citizens; this may actually cause harm to would-be migrant workers by decreasing incentives for host countries to provide them with beneficial employment opportunities. ${ }^{255}$ Instead, the scope to which equal treatment of migrant workers must be enforced has been defined as the four fundamental rights. ${ }^{256}$ Whether such a model is adopted or not, the putting forward of such ideas exposes fundamental problems with the North/South dichotomy and suggests the possibility of policy adopting a critical and more nuanced approach to it.

\section{The Theological Dichotomies}

The proposed model also challenges the theological dichotomies discussed above. ${ }^{257}$ The Liberalisation/Protectionism dichotomy is challenged by providing countries with the choice to "opt out" of the WTO's international standards enforcement regime if they see this as an effort to unfairly undermine their competitive advantage. ${ }^{258}$ This will also give countries that consider the jobs/standards dichotomy to be based on false premises, at least with respect to the fundamental labour rights, the chance to demonstrate the notion that the two can exist - and be improved - simultaneously. ${ }^{259}$ By requiring countries to be accountable to some degree with respect to labour rights within their own jurisdictions, however, the model perceives the inherent Protectionism within Liberalism; the "invisible hand"

\footnotetext{
${ }^{253}$ TREBILCOCK \& HOWSE, supra note 14, at 461. Admittedly, however, the remedies under the NAALC are often insufficient in proportion to the effort it takes to have them awarded, and seeking authorised sanctions is a virtual impossibility: see, eg, Human Rights Watch, supra note 100. See also Champion, supra note 224 , at 234-5.

${ }^{254}$ See above Parts III(B) and III(C). See also Cleveland, supra note 10, at 158-9.

${ }^{255}$ I have had the personal experience of spending two months in an Indonesian village from which many migrant workers are sourced to work in the Middle East. All returned workers I spoke to agreed that the working conditions were not good, but none regretted the opportunity to work for two years and bring home enough savings to make productive investments in the local aquaculture industry.

${ }^{256}$ To take too broad a scope may be analogous to the conceptual violence that Pahuja warns of when a critical cause is pushed into its "master subject": Pahuja, supra note 43, at 41.

${ }^{257}$ See above Part III(C).

${ }^{258}$ As mentioned above, this will not absolve those countries from their responsibilities to the ILO under the ILO Declaration - it simply means those countries will not be held accountable by the WTO.

${ }^{259}$ See, eg, James Heintz, Beyond Sweatshops: Employment, Labor Market Security and Global Inequality 36 ANTIPODE 222, 223-4 (2004).
} 
of trade law is acknowledged as being unable to detect all forms of subsidies. ${ }^{260}$ Similarly, addressing the issue of freedom of movement is an implicit acknowledgment that Protectionism exists within the system of Liberal trade law.

The concept of labour linkage itself is inherently antagonistic towards the notion that Economic Development, as achieved by trade at all costs, is the sole antidote to Poverty. Through presenting a number of values that may "trump" trade in certain circumstances, the proposed model attempts to reinforce the notion that trade is simply a means to an end. If looked at directly, these trumping values pertain to core rights in the workplace and labour market. However, given that these rights are in many cases preconditions for more general human rights ${ }^{261}$ and the development of civil society, ${ }^{262}$ the challenge labour linkage poses to Economic Development is a broad one. Even where a country opts out under the model, the requirement that it continue to uphold the rule of law with regard to the fundamental freedoms may itself be conducive to legal and judicial development. In this way, the requirement may be understood as permitting the prioritisation of Economic Development while also challenging the "development as Economic Development alone" paradigm. ${ }^{263}$ Similarly, the permission granted under the proposed model for countries to treat products differently according to whether their Production was carried out in accordance with international or domestic labour standards (whatever the case may be), challenges the traditional Consumption/Production dichotomy while reconstructing it in a way that does not permit countries to impose their own standards of Production on others.

\section{$4 \quad$ The Regime Dichotomies}

The proposed model challenges the regime dichotomies ${ }^{264}$ to perhaps an even greater extent than it challenges any of the other traditional conceptual differentiations. The universalist/relativist dichotomy is challenged by the fact that on one hand the model is "relativist" in that countries are given the autonomy to opt in or opt out of the enforcement of international labour rights. On the other hand, however, the notion that countries which have opted out should instead explain their non-enforcement and enforce their own standards, challenges the notion that labour is a matter that falls entirely within the scope of national sovereignty. This is consistent with an emerging notion, as articulated in the Vienna Declaration on Human Rights, ${ }^{265}$ that human rights can be simultaneously universal and relative. ${ }^{266}$ An

\footnotetext{
${ }^{260}$ Pahuja, supra note 43 , at 51.

${ }^{261}$ See, eg, Human Rights Watch, supra note 100. See also Champion, supra note 224, at 238.

${ }^{262}$ See generally Paul de Waart, Minimum Labour Standards in International Trade from a Legal Perspective in International Trade and Labour Standards from an Economic Perspective in Challenges to THE New World Trade Organization 245-64 (Pitou van Dijck \& Gerrit Faber eds.,1996).

${ }^{263}$ Sen, supra note 183 , at 9.

${ }^{264}$ See above Part III(D).

${ }^{265}$ Vienna Declaration and Programme of Action: Report of the World Conference on Human Rights, U.N. Doc A/CONF.157/23 (1993).
} 
application of the "margin of appreciation" doctrine would also see that domestic circumstances are taken into account in the context of applying international standards.

The key role that the ILO would play in dispute settlement within the proposed model questions the legitimacy of the traditional WTO/ILO dichotomy. Given that under the model countries will require detailed information about each other's labour laws and practices, the ILO would also be set to play a key ongoing informative role, outside dispute settlement. The various commitments, explanations and complaints tendered to the WTO under the model would likewise put it in a position to inform the "soft approach" of the ILO. As such, while problematising the notion that trade should be left entirely to the WTO and labour to the ILO, the model does not fuse the two. In this way, both a "hard" and a "soft" approach are made possible under the model.

The inclusion in the model of the "hard" approach of authorised sanctions is obviously an affront to the sanctions/welfare dichotomy. When sanctions are examined closely, without beginning with the assumption that they are always inimical to welfare, it is possible to conceive of circumstances where sanctions may actually support people's welfare, not just in the sanctioning country, but also in the sanctioned country. This is particularly the case after one considers the actors dichotomy, which serves to foreground national interests and hide trans- and sub-national exploitation. ${ }^{267}$ That being said, however, the model is sensitive of the fact that in most cases sanctions will indeed be incompatible with welfare. It is for this reason that the model seeks to limit the types of sanctions available and the circumstances in which they can be authorised. This includes the use of better-targeted sanctions, the application of the "harm calculus test"268 and provisions for LEDCs who are authorised to sanction but cannot afford to do so. The anti-welfare impact of sanctions is also checked by the ability of countries under the model to exempt themselves from WTO enforcement of international standards. Given all these prerequisites for the authorisation of sanctions, it is hoped that sanctions will only exist either as a threat to countries that do not bargain in good faith, or as a tool of "lesser evil" relative to all other options (including taking no action). In other words, the model challenges the welfare/sanctions dichotomy by proposing that sanctions be authorised in those rare circumstances where the dichotomy does not seem to hold true.

\footnotetext{
${ }^{266}$ Donoho, supra note 233, at 415. For example, Paragraph 1 of the Vienna Declaration emphasises the "universal nature" of human rights while Paragraph 5 states that "particularities... must be borne in mind".

${ }^{267}$ See above Part III(B). As discussed above in Part IV(B)(2), it would be possible for citizens of Country A to sanction products from Country B that have actually been produced by a Country A corporation.

${ }^{268}$ That sanctions can only be authorised when their imposition would result in less harm to the sanctioned population than the non-enforcement of standards which has given rise to the application for authorisation: See above Part IV(A).
} 


\section{Concluding Remarks}

The aim of this paper has been to encourage new directions within the discourse on linkage between labour and the WTO. After briefly discussing the background to the discourse's current stalemate, the paper attempted to demonstrate how the arguments within the discourse have been based on a number of "conceptual differentiations". These have taken the form of dichotomies such as trade/non-trade; North/South; Liberalisation/Protectionism; Economic Development/Poverty; Consumption/Production; universalist/relativist; WTO/ILO; and sanctions/welfare. A closer examination of these dichotomies demonstrated how they are often founded on unstable premises; in many cases neither the dichotomies themselves, nor the portrayal of certain arguments as belonging to one or the other side of a dichotomy, appeared particularly clear cut after a serious analysis. In the most part, the analysis problematised anti-linkage arguments. However, the analysis of the Liberalisation/Protectionism dichotomy also revealed some hypocrisy on the part of prolinkage advocates. In addition, the very fact that the problems associated with these conceptual differentiations have not been clearly and frequently articulated by prolinkage proponents is a deficiency in itself. With the aim of prompting a more dynamic debate on these problems, the paper then presented a potential linkage model. In finding that it is possible to suggest a model that challenges some of the traditional conceptual differentiations, this author therefore welcomes further and more sophisticated efforts to present theoretical frameworks and policy options that challenge established ways of understanding labour linkage.

This author is confident that the labour linkage discourse will continue and become more dynamic. With the WTO approaching its tenth anniversary and its impact becoming more and more felt throughout the world and across a range of social, political, cultural and economic institutions, attention to the trade-labour link is only likely to grow and develop into serious political pressure. This author senses that the WTO itself recognises that its legitimacy rests on it being perceived as moving beyond pretending to be involved only with "trade" as defined by the narrowest definition of the term. At some point, it is likely the academic dimension to the labour linkage discourse will cease, and labour linkage will instead become an object of horse-trading in the realms of the realpolitik. Countries which currently oppose labour linkage may then, understandably, seek to use it as leverage to enforce past promises about agricultural subsidies, textile quotas and other pressing trade concerns. ${ }^{269}$ The result may not be part of a "coherent program for world order", but this need not necessarily be a problem. ${ }^{270}$

The fact that the labour linkage discourse may evolve into something subject to the political constraints of trade negotiations should not discourage us from making the

\footnotetext{
${ }^{269}$ Thomas, supra note 67, at 402. See also Leebron, supra note 69, at 25.

${ }^{270}$ Koskenniemi, supra note 44 , at 500 .
} 
discourse as robust as possible. After all, it is only through exploring new ground that labour linkage may enter trade negotiations, and the ground covered by the discourse will inevitably shape the political deals made therein. The labour linkage discourse may also have something to offer, and to learn from, other linkage discourses, such as the discourse on the environment-trade link. ${ }^{271}$ However, the uniqueness of each discourse must be kept in mind; Thomas reminds us, for example, that international environmental law does not have the same degree of consensus as international labour law on the issue of core rights or principles. ${ }^{272}$ Another dimension to the discourse on the trade-labour link is that it need not be limited to the WTO, as there is great potential for the link to impact upon the work of the International Monetary Fund, World Bank, and various United Nations agencies. ${ }^{273}$

To be sure, linkage is not the only way to improve global labour conditions. Other avenues also need to be pursued, including diplomatic approaches; the liberalisation of migration; extraterritorial application of domestic laws to transnational corporations; awareness-raising campaigns; international corporate governance reform; pursuing the labour-related aspects of anti-dumping and other commercial competition laws; corporate social responsibility; product labelling; and the effective transnationalisation of unions. Indeed, focussing too heavily on linkage may "background" these avenues. ${ }^{274}$ However, taking this to mean that labour linkage should be dropped altogether, without a thorough analysis, would be falling prey to the all/nothing dichotomy. It would also be an affront to the thesis of this paper because, as this paper has attempted to demonstrate, the labour linkage discourse deserves better than stale binary logic.

\footnotetext{
${ }^{271}$ After all, many of the resources I have used in this paper have discussed linkage in the context of labour and the environment.

${ }^{272}$ Thomas, supra note 67, at 375-7.

${ }^{273}$ See, eg, Mehmet, Mendes and Sinding, supra note 78, at 212-15. See also Stiglitz, supra note 131. The relationship between labour linkage and the ILO, for example, has been discussed at various junctures in this paper.

${ }^{274}$ See generally KENNEDY, supra note 74.
} 